\title{
a7 Nicotinic Receptor Agonists: Potential Therapeutic Drugs for Treatment of Cognitive Impairments in Schizophrenia and Alzheimer's Disease
}

\author{
Jun Toyohara, and Kenji Hashimoto*
}

Division of Clinical Neuroscience, Chiba University Center for Forensic Mental Health, Chiba, Japan

\begin{abstract}
Accumulating evidence suggests that $\alpha 7$ nicotinic receptors ( $\alpha 7 \mathrm{nAChRs})$, a subtype of $\mathrm{nAChRs}$, play a role in the pathophysiology of neuropsychiatric diseases, including schizophrenia and Alzheimer's disease (AD). A number of psychopharmacological and genetic studies shown that $\alpha 7$ nAChRs play an important role in the deficits of P50 auditory evoked potential in patients with schizophrenia, and that $\alpha 7 \mathrm{nAChR}$ agonists would be potential therapeutic drugs for cognitive impairments associated with P50 deficits in schizophrenia. Furthermore, some studies have demonstrated that $\alpha 7 \mathrm{nAChRs}$ might play a key role in the amyloid- $\beta$ (A $\beta$ )-mediated pathology of $\mathrm{AD}$, and that $\alpha 7 \mathrm{nAChR}$ agonists would be potential therapeutic drugs for $\mathrm{A} \beta$ deposition in the brains of patients with $\mathrm{AD}$. Interestingly, the altered expression of $\alpha 7 \mathrm{nAChRs}$ in the postmortem brain tissues from patients with schizophrenia and AD has been reported. Based on all these findings, selective $\alpha 7 \mathrm{nAChR}$ agonists can be considered potential therapeutic drugs for cognitive impairments in both schizophrenia and $\mathrm{AD}$. In this article, we review the recent research into the role of $\alpha 7 \mathrm{nAChRs}$ in the pathophysiology of these diseases and into the potential use of novel $\alpha 7 \mathrm{nAChR}$ agonists as therapeutic drugs.
\end{abstract}

Keywords: $\alpha 7$ Nicotinic receptors, Cognition, Schizophrenia, Alzheimer's disease.

\section{$\alpha 7$ NICOTINIC ACETYLCHOLINE RECEPTORS}

$(S)-(-)-$ Nicotine (Fig. 1, hereafter simply nicotine), the main addictive component of tobacco, activates and desensitizes nicotinic acetylcholine receptors (nAChRs). In the central nervous system (CNS), nAChRs normally respond to acetylcholine (ACh) (Fig. 1) and modulate neuronal excitability and synaptic communication [1-4]. The health consequences of smoking and the mechanisms involved in nicotine dependence continue to be subjects of great interest [5-9]. In addition, recent attention has been directed to the potential role of nAChRs in diseases and therapeutic targets [10-23].

The nAChRs are ligand-gated ion channels that are distributed throughout the human CNS and that each consists of five subunits (a combination of $\alpha$ and $\beta$ subunits). At present, nine $\alpha(\alpha 2-\alpha 10)$ and three $\beta$ ( $\beta 2-\beta 4)$ subunits have been identified and cloned in humans. The numerous combinations of $\alpha$ and $\beta$ subunits or of $\alpha$ subunits alone can generate many subtypes of nAChRs with different physiologies, pharmacologies and anatomical distributions [4]. Two major subtypes exist in the brain, those comprised of $\alpha 4 \beta 2$ and those comprised of $\alpha 7$ subunits. The former contribute $>90 \%$ of the high affinity binding sites for nicotine in the rat brain [24]. The low affinity binding sites ( $\alpha 7$ subunits) for nicotine are recognized by their nanomolar

*Address correspondence to this author at the Division of Clinical Neuroscience, Chiba University Center for Forensic Mental Health, 1-8-1 Inohana, Chiba 260-8670, Japan; Tel: +81-43-226-2147;

Fax: +81-43-226-2150; E-mail: hashimoto@ faculty.chiba-u.jp affinity for $\alpha$-bungarotoxin [25]. The $\alpha 7 \mathrm{nAChRs}$ have an unusually high permeability to $\mathrm{Ca}^{2+}$ compared to other subtypes and exhibit exceptionally rapid desensitization following exposure to agonists [8, 26-30]. Choline (Fig. 1) is an essential physiological component of the cerebrospinal fluid (CSF) and is important for the structural integrity of cell membranes, ACh synthesis, and lipid and cholesterol transport and metabolism. Several lines of evidence suggest that choline is a full agonist of $\alpha 7 \mathrm{nAChRs}$, but not other nAChR subtypes [31-34].

The $\alpha 7$ nAChRs are assumed to comprise five $\alpha 7$ subunits and to differ from other subtypes of nAChRs. In particular, the $\alpha 7 \mathrm{nAChRs}$ may play a distinct role in regulating neuronal plasticity. By elevating intracellular $\mathrm{Ca}^{2+}$ levels in discrete neuronal locations, these ligand-gated ion channels may influence numerous physiological processes in the developing and adult CNS [4, 23, 26, 27, 35]. Several lines of evidence suggest that both pre- and postsynaptic $\alpha 7$ nAChRs modulate neurotransmitter release in the brain through $\mathrm{Ca}^{2+}$-dependent mechanisms, and that the $\alpha 7$ nAChRs play a role in regulating neuronal growth and differentiation in the developing CNS [4, 26, 35-38]. Furthermore, it has been proposed that intracellular $\mathrm{Ca}^{2+}$ may be coregulated by N-methyl-D-aspartate (NMDA) receptors and $\alpha 7 \mathrm{nAChRs}$ in the brain [26]. Together with NMDA receptors, postsynaptic $\alpha 7 \mathrm{nAChRs}$ may serve to regulate intracellular $\mathrm{Ca}^{2+}$ levels in neurons, whereas presynaptic $\alpha 7$ nAChRs could serve as a feedback mechanism for modulating glutamatergic transmission. Thus, it is possible that a close interaction between cholinergic and glutamatergic pathways, mediated by $\alpha 7 \mathrm{nAChRs}$ and NMDA receptors, may play a role in the pathophysiology of 


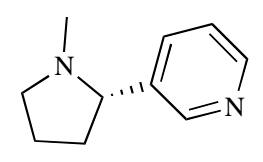

(S)-(-)-nicotine

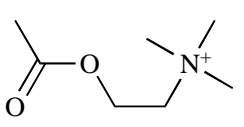

acetylcholine

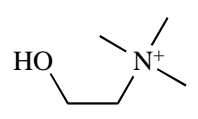

Choline

Fig. (1). Chemical structures of (S)-(-)-nicotine, acetylcholine (ACh) and choline.

neuropsychiatric diseases such as schizophrenia and Alzheimer's disease (AD) [4, 23, 26, 35-41].

In this article, we review the role of $\alpha 7 \mathrm{nAChRs}$ in the pathophysiology of neuropsychiatric diseases such as schizophrenia and $\mathrm{AD}$. In addition, we also review recent advances in the potential use of $\alpha 7 \mathrm{nAChR}$ agonists as therapeutic drugs for these diseases.

\section{SCHIZOPHRENIA AND $\alpha 7 \mathrm{nAChRs}$}

The binding sites ( $\alpha 7$ subtype) labeled by $\left[{ }^{125} \mathrm{I}\right] \alpha-$ bungarotoxin are different from the high affinity binding sites ( $\alpha 4 \beta 2$ subtype) for nicotine [42]. In the hippocampus, $\left[{ }^{125} \mathrm{I}\right] \alpha$-bungarotoxin binds most intensely to inhibitory interneurons in the CA3 region of Ammon's horn and in the hilus of the dentate gyrus [43]. The authors of the latter study subsequently suggested that inhibitory interneurons with $\alpha 7$ nAChRs are possible candidates for medication of the habituation of auditory responses in the hippocampus because activation of the interneurons via $\alpha 7 \mathrm{nAChRs}$ would increase the inhibitory synaptic input to pyramidal neurons and thereby diminish the responsiveness of these pyramidal neurons to sensory stimulation [44]. This parallels studies of postmortem human tissue that documented a decreased expression of hippocampal $\alpha 7 \mathrm{nAChRs}$ in schizophrenic patients [45]. It has been shown that $\left[{ }^{125} \mathrm{I}\right] \alpha$-bungarotoxin binding is reduced in the thalamic reticular nucleus of schizophrenic subjects [46], and that $\alpha 7 \mathrm{nAChR}$ protein levels are reduced in the frontal cortex in patients with schizophrenia [47]. Furthermore, Marutle et al. [48] observed a reduction of $\alpha 7 \mathrm{nAChRs}$ but an increase of $\left[{ }^{3} \mathrm{H}\right]$ cytisine binding to $\alpha 4 \beta 2 \mathrm{nAChRs}$ in the cingulate cortex of schizophrenic patients. Thus, it seems that schizophrenic patients have fewer $\alpha 7 \mathrm{nAChRs}$ in the hippocampus, a condition which may lead to failure of cholinergic activation of inhibitory interneurons, clinically manifested as decreased gating of the response to sensory stimulation $[23,37,44,49$, 50].

In regard to the search for peripheral biological markers for schizophrenia, Perl et al. [51] investigated the mRNA levels of $\alpha 7 \mathrm{nAChRs}$ in peripheral blood lymphocytes of schizophrenic patients and healthy controls. They found a significant reduction of $\alpha 7 \mathrm{nAChR}$ mRNA levels on lymphocytes of schizophrenic patients [51]. This reduction was not a result of medication, because the non-medicated patients displayed the same levels of reduction in $\alpha 7 \mathrm{nAChR}$ mRNA. In addition, the possibility that the observed decrease in $\alpha 7$ nAChR mRNA levels resulted from nicotine consumption in smoking was excluded, because healthy smokers exhibited the same levels of $\alpha 7$ nAChR mRNA as non-smokers [51]. These findings suggest that mRNA levels of $\alpha 7 \mathrm{nAChRs}$ in peripheral blood lymphocytes may serve as a reliable peripheral biological marker for schizophrenia.

\section{SENSORY GATING DEFICITS IN SCHIZOPHRENIA AND $\alpha 7$ nAChRs}

Our knowledge of the deficits of sensory gating in schizophrenia derives from the clinical observation that patients report failures of information processing characterized by poor sensory gating [44, 52-54]. The underlying problem is evident in the inability of people with schizophrenia to adequately filter their response to incoming sensory stimulation, as measured by their inhibitory processing of the P50 auditory evoked potential. The P50 auditory evoked potential is a positive electroencephalographic waveform that occurs $50 \mathrm{msec}$ after presentation of an auditory stimulus. When pairs of auditory stimuli are presented, with a $500 \mathrm{msec}$ interstimulus interval, schizophrenic patients fail to adequately inhibit the P50 response to the second stimulus. Normal subjects, however, have significantly reduced responses to the second stimulus [44, $52,54,55]$. The reduced response to the second stimulus reflects inhibitory processing of the information that may function to protect the individual from being overwhelmed by incoming, repetitive sensory information. It is known that nicotine transiently normalizes the deficits in P50 auditory evoked potential in schizophrenic patients $[56,57]$.

Genetic linkage analysis of deficits in P50 auditory evoked potential in families of patients with schizophrenia has revealed a peak LOD score at 15q13-q14, and the LOD score was 5.3 (theta $=0.00$ ) at the D15S1360 marker, which is located in intron 2 of the gene for the $\alpha 7 \mathrm{nAChR}$ subunit (CHRNA7) [58]. The CHRNA7 gene is located on chromosome 15q13-q14, a region linked with schizophrenia in several earlier studies $[59,60]$. The CHRNA7 has a partial duplication of exons 5-10, including the intervening introns (CHRFAM7) that map approximately $0.5 \mathrm{Mb}$ proximal to the full-length CHRNA7 gene [61]. The D15S1360 microsatellite repeats, in intron 2 of the CHRNA7 gene, cosegregate with an auditory gating deficit in family linkage studies of schizophrenic patients [58]. Furthermore, in a mutation screening of the CHRNA7 gene from schizophrenics and controls, Leonard et al. [62] identified the promoter polymorphisms that decreased the subunit transcription and P50 inhibition in schizophrenia. Moreover, an association has been demonstrated between the homozygous 113 bp allele on the D15S1360 polymorphism of the CNRNA7 gene and smoking risk in schizophrenia [63]. Taken together, these results suggest that the CHRNA7 gene is likely susceptible to the deficits of P50 sensory gating in schizophrenia [10, 23, 44, 49, 50, 53, 58, 63-67]. Interestingly, a 2 bp deletion in exon 6 of CHRFAM7A, which disrupts the hybrid gene for the CHRNA7 gene, was associated with episodic memory performance in schizophrenia, suggesting that the CHRFAM7A/CHRNA7 
locus plays a role in modulating episodic memory function [68].

Taken together, these results suggest that $\alpha 7 \mathrm{nAChRs}$ likely play an important role in the deficits of P50 auditory evoked potential in patients with schizophrenia, and that $\alpha 7$ nAChR agonists would be potential therapeutic drugs for cognitive impairments associated with P50 deficits in schizophrenia [10, 23, 64, 65, 69, 70].

\section{ALZHEIMER'S DISEASE (AD) AND $\alpha 7$ nAChRs}

Identification of the loss of cholinergic neurons in the basal forebrain and of cholinergic innervations of the cerebral cortex in Alzheimer's disease (AD) [71-73] was followed by investigations into the involvement of cholinergic receptors. With regard to $\alpha 7 \mathrm{nAChR}$ protein expression, the investigations show conflicting results. For example, it has been reported that there is no significant relation between $\left[{ }^{125} \mathrm{I}\right] \alpha$-bungarotoxin binding in the frontal cortex and AD [74, 75]. Although an early study of Davies and Feisullin [74] reported a $40 \%$ reduction in $\left[{ }^{125} \mathrm{I}\right] \alpha-$ bungarotoxin binding in the temporal cortex of patients with AD, this was not replicated [76]. The results of most studies show no significant $[77,78]$ or minor [79] loss of $\alpha 7$ subunit protein levels in the temporal cortex of patients with $\mathrm{AD}$, although a reduction has been demonstrated in the frontal cortex of such patients [80]. In the hippocampus, a $25 \%$ reduction in $\left[{ }^{125} \mathrm{I}\right] \alpha$-bungarotoxin binding (as revealed using membrane homogenate) was observed in patients with AD relative to age-matched control subjects, although the number of control cases studied was small [76]. However, an autoradiographic investigation did not detect significant changes in $\left[{ }^{125} \mathrm{I}\right] \alpha$-bungarotoxin binding in a large series of patients with $\mathrm{AD}$, but rather, in common with Burghaus et al. [79], a considerable variation in the density of the $\alpha 7$ receptor subtype was seen among patients with AD [81]. Such variation in $\alpha 7 \mathrm{nAChR}$ expression may reflect disease severity, and it should be evaluated in cohorts of patients with detailed clinical and pathological assessments. Despite a reported $36 \%$ reduction in $\alpha 7$ protein expression in the hippocampal formation of patients with AD [77], a $65 \%$ increase in $\alpha 7$ subunit mRNA expression has also been demonstrated in patients with AD [76], suggesting the possibility of a compensatory mechanism. Recently, Counts et al. [82] reported that $\alpha 7 \mathrm{nAChR}$ was up-regulated in cholinergic basal forebrain neurons in patients with $\mathrm{AD}$. In the same study, dysfunction of the basocortical cholinergic projection neurons of the nucleus basalis (NB) was correlated with cognitive deficits in AD. The authors found that cholinergic NB neurons displayed a statistically significant up-regulation of $\alpha 7 \mathrm{nAChR}$ mRNA expression in subjects with mild to moderate AD compared with those with no cognitive impairment (NCI) or mild cognitive impairment $(\mathrm{MCI})(\mathrm{P}<0.001)$. The expression levels of $\alpha 7$ nAChRs were inversely associated with the Global Cognitive Score and with Mini-Mental State Examination performance. Very recently, Ikonomovic et al. [83] found that increased $\alpha 7 \mathrm{nAChR}$ binding of $\left[{ }^{3} \mathrm{H}\right]$ methyllycaconitine (MLA)( Fig. 2) was associated with diagnosis of AD based on the National Institute on Aging-Reagan Institute criteria $(\mathrm{P}=0.02)$ and, albeit weakly, the presence of cortical $\beta$ amyloid $(\mathrm{A} \beta)$ plaque in $\mathrm{AD}(\mathrm{P}=0.08)$. Taken together, these results suggest that the up-regulation of $\alpha 7 \mathrm{nAChR}$ may occur as a compensatory mechanism to maintain neuronal function during AD progression [83]. Furthermore, it has been reported that genetic variation (rs6494223) in the CHRNA7 gene is associated with delusional symptoms in AD [84], suggesting that $\alpha 7 \mathrm{nAChRs}$ may be a suitable target for the treatment of AD with psychosis. In addition, patients with Alzheimer's disease have also been reported to show deficits of P50 auditory sensory gating relative to controls [85]. It has also been suggested that the disturbed sensory gating in patients with AD might result from cholinergic dysfunction or $\alpha 7 \mathrm{nAChR}$ loss.

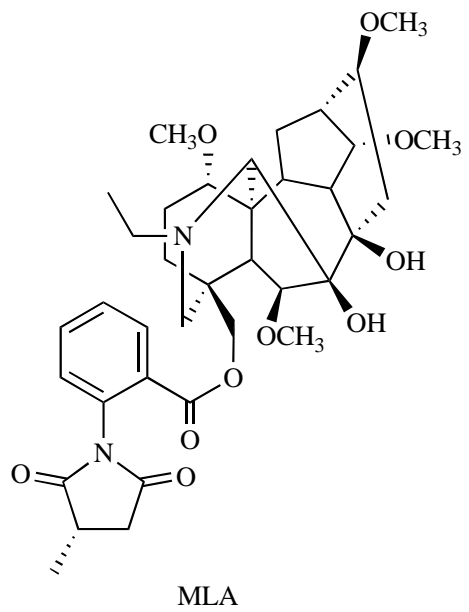

Fig. (2). Chemical structure of MLA.

\section{$\beta$-AMYLOID AND $\alpha 7$ nAChRs}

$\beta$-Amyloid (A $\beta$ ) binds with high affinity to neuronal $\alpha 7$ nAChRs [86, 87]. This interaction leads to intraneuronal accumulation of $\mathrm{A} \beta_{1-42}\left(\mathrm{~A} \beta_{42}\right)-\alpha 7 \mathrm{nAChR}$ complexes [88], rapid tau phosphorylation [89], severe impairment of $\alpha 7$ nAChR channels [90, 91], cholinergic neurotransmission defects [92], and neuronal cell death [86]. These findings indicate that chronic perturbation of the $\alpha 7 \mathrm{nAChRs}$ by $\mathrm{A} \beta_{42}$ in $\mathrm{AD}$ brains could cause neuronal dysfunction and neurodegeneration, resulting in the accumulation of $A \beta$-rich amyloid plaques and phosphorylated tau-containing neurofibrillary tangles (NFTs). Recently, Dziewczapolski et al. [93] showed that, despite the presence of high amounts of amyloid precursor protein (APP) and amyloid deposits, deleting the $\alpha 7 \mathrm{nAChR}$ subunit in the mouse model of AD leads to protection from dysfunction in synaptic integrity (pathology and plasticity) and learning and memory behavior. Hence, disrupting the $\mathrm{A} \beta_{42}-\alpha 7 \mathrm{nAChR}$ interaction may represent a novel approach to reducing $A \beta_{42}$-mediated functional deficits, neurodegeneration, and possibly the clinicopathological features of AD.

Taken together, these results suggest that $\alpha 7 \mathrm{nAChRs}$ are likely to play a key role in the $\mathrm{A} \beta$-mediated pathology of $\mathrm{AD}$, and that $\alpha 7 \mathrm{nAChR}$ agonists would be potential therapeutic drugs for $\mathrm{AD}[39,40,93,94]$.

\section{$\alpha 7$ NICOTINIC RECEPTOR AGONISTS}

\section{3-(2,4)-Dimethoxybenzilidine Anabaseine (DMXB-A; Also Known as GTS-21)}

While there are a number of nicotinic receptor agonists known to be selective for the $\alpha 4 \beta 2$ subtype, there are some 
<smiles>c1cncc(C2=NCCCC2)c1</smiles>

Anabaseine<smiles>CN(C)c1ccc(/C=C2\CCCN=C2c2cccnc2)cc1</smiles>

DMAB<smiles>c1cncc(C2CCCCN2)c1</smiles>

Anabasine<smiles>CN(C)c1ccc(/C=C/C=C2\CCCN=C2c2cccnc2)cc1</smiles>

DMAC<smiles>COc1ccc(/C=C2\CCCN=C2c2cccnc2)c(OC)c1</smiles>

DMXB-A (or GTS-21)<smiles>COc1cc(O)ccc1/C=C1\CCCN=C1c1cccnc1</smiles>

4-OH DMXB-A

Fig. (3). Chemical structures of anabaseine, anabasine, DMXB-A, DMAB, DMAC and 4-OH DMXB-A.

agonists which bind the $\alpha 7$ nAChRs selectively over other subtypes [13, 18, 20]. Anabaseine (2-(3-pyridyl)-3,4,5,6tetrahydropyridine) (Fig. 3), a naturally occurring substance in nemertines, is an agonist at the neuromuscular junction [95] and is structurally related to nicotine. The better known compound anabasine (neonicotine; 3-(2-piperidinyl)pyridine) (Fig. 3) is a weak nicotinic alkaloid found in tobacco that lacks the imine double bond present in anabaseine. Three analogues of anabaseine, 3-(2,4)-dimethoxybenzilidine anabaseine (DMXB-A; also known as GTS-21), 3-(4)dimethylaminobenzylidine anabaseine (DMAB), and 3-(4)dimethylaminocinnamylidine (DMAC), have been reported to be functionally selective for the $\alpha 7$ nAChRs [96] (Fig. 3). Compared with anabaseine and the other derivatives, DMAC was found to be the most potent at displacing $\left[{ }^{125} \mathrm{I}\right] \alpha-$ bungarotoxin binding (putative $\alpha 7$ subtype) and the least potent at displacing $\left[{ }^{3} \mathrm{H}\right]$ cytisine binding (putative $\alpha 4 \beta 2$ subtype) to brain membranes. These anabaseine derivatives were partial agonists at $\alpha 7 \mathrm{nAChRs}$ [96]. Furthermore, DMXB-A bound to human $\alpha 4 \beta 2$ nAChRs $(K \mathrm{i}=20 \mathrm{nM}) 100$ fold more potently than to human $\alpha 7 \mathrm{nAChRs}$, and was 18 and 2-fold less potent than (-)-nicotine at human $\alpha 4 \beta 2$ and $\alpha 7$ nAChRs, respectively [97]. The primary human metabolite, 3-(4-hydroxy-2-methoxybenzylidine) anabaseine (4-OH DMXB-A; Fig. 3), of DMXB-A exhibited a similar level of efficacy for human $\alpha 7 \mathrm{nAChRs}[98,99]$.

Initial (phase I) clinical studies on DMXB-A have been reported [100]. DMXB-A was administered to 87 healthy volunteers. Initially, the effects of single doses (range, 1-250 $\mathrm{mg}$ ) were assessed. The elimination half-life ranged between 0.5 and $1.0 \mathrm{~h}$ for DMXB-A and its major phase I metabolite,
4-OH DMXB-A. No serious adverse effects were reported at these doses. At twice daily doses of 75 and $150 \mathrm{mg}$ for 5 days, DMXB-A improved the cognitive function of young adult volunteers. Furthermore, DMXB-A improved longterm memory as well as working memory and attention, as measured by the Cognitive Drug Research test battery [100]. A randomized, placebo-controlled, multiple dose study of the safety, pharmacokinetics and cognitive effects of DMXB-A in healthy volunteers was also reported [101]. A total of 18 subjects were randomized to receive DMXB-A $(25,75$, and $150 \mathrm{mg})$ or a placebo administered three times daily for 5 days with a 10 day washout period between drugtaking periods. DMXB-A was well tolerated up to doses of $450 \mathrm{mg} /$ day, with no clinically significant safety findings. Peak plasma levels $\left(\mathrm{C}_{\max }\right)$ were achieved at 1-1.4 $\mathrm{h}$ after the first dose and 1-1.2 $\mathrm{h}$ after 5 days of dosing. $\mathrm{C}_{\max }$ and the area under the plasma concentration-time curve (AUC) of DMXB-A and metabolite 4-OH-DMXB-A increased in a dose-related manner. DMXB-A showed statistically significant enhancement of three measures of cognitive function (attention, working memory, and episodic second memory) compared to placebo. A relationship between exposure to DMBX-A and the magnitude of the cognitive response was apparent, with a maximal effect observed for doses between 75 and $150 \mathrm{mg}$ three times a day.

Because DMXB-A appeared safe and promising for enhancing cognition, this drug was studied in schizophrenic patients to determined whether the $\alpha 7 \mathrm{nAChRs}$ activation is responsible for the normalization of the P50 auditory evoked potential deficits in schizophrenia [102]. Additionally, the safety and effects of DMXB-A on neurocognition in 
schizophrenia patients were also evaluated. DMXB-A was administered in a double-blind, placebo-controlled crossover design to 12 male and female non-smokers with schizophrenia. DMXB-A was administered orally (150 or 75 $\mathrm{mg}$ ) followed $2 \mathrm{~h}$ later by a half dose $(75$ or $37.5 \mathrm{mg}$ ). DMXB-A improved performance on both the repeatable battery for assessment for neuropsychological status (RBANS) total scale score and the attention scale. DMXB-A also normalized the $\mathrm{P} 50$ ratio as well as the test wave amplitude, a more specific measure of inhibition.

On the basis of this initial positive trial, a phase 2 trial was conducted to assess whether the cognitive effects would continue during longer-term administration and whether the clinical ratings would also change [103]. Thirty-one subjects with schizophrenia received DMXB-A at one of two different doses or a placebo for 4 weeks in a three-arm, twosite, double-blind, crossover phase 2 trial. The doses were those used in the phase 1 trial. The Measurement and Treatment Research to Improve Cognition in Schizophrenia (MATRICS) Consensus Cognitive Battery developed by the National Institute of Mental Health was used to assess cognitive effects, and the Scale for the Assessment of Negative Symptoms (SANS) and Brief Psychiatry Rating Scale (BPRS) were used to assess the clinical effects. Subjects continued their current antipsychotic drug during the trial and were nonsmokers. There were no significant differences in the MATRICS cognitive measures between DMXB-A and placebo over the three treatment arms, but patients taking the higher DMXB-A dose experienced significant improvement in the SANS total score and nearly significant improvement in the BPRS total score. Improvement was most notable on the SANS anhedonia and alogia subscales. Examination of the first treatment arm showed effects of DMXB-A on the attention/vigilance and working memory MATRICS domains, compared to baseline. There were, however, increased reports of nausea and restlessness during DMXB-A treatment. Nausea occurred in patients $(45 \%)$ at the higher dose of DMXB-A, suggesting the known effects of nicotinic agonists on gastrointestinal motility [103]. Considering the high incidence of nausea in the treatment with $\alpha 7 \mathrm{nAchR}$ agonists, $\alpha 7 \mathrm{nAchR}$ agonists with 5-hydroxytryptamine-3 $\left(5-\mathrm{HT}_{3}\right)$ receptor antagonism would be potential therapeutic drugs for cognitive impairments as well as negative symptoms in schizophrenic patients, since the $5-\mathrm{HT}_{3}$ receptor antagonists have been used for the treatment of nausea [104].

\section{AstraZeneca}

Researchers at AstraZeneca reported the profile of ARR17779, (-)-spiro[1-azabicyclo[2.2.2] octane-3,5'-oxazolidin $-2^{\prime}$-one] (Fig. 4), a potent full agonist of the $\alpha 7 \mathrm{nAChRs}$ that is highly selective for the $\alpha 7$ subtype over the $\alpha 4 \beta 2$ subtypes
[105]. AR-R17779 has been widely used as a selective full agonist of the $\alpha 7$ nAChRs. For example, AR-R17779 failed to stimulate locomotor activity in both nicotine-nontolerant and -sensitized rats, whereas nicotine and the putative agonist SIB1765F, [ \pm ]-5-ethynyl-3-(1-methyl-2-pyrrolidiny1)pyridine fumarate (Fig. 4) [100], of $\alpha 4 \beta 2$ nAChRs increased the activity under both experimental conditions, suggesting a negligible role of $\alpha 7 \mathrm{nAChRs}$ in nicotineinduced hyperlocomotion and reward in the rat [106]. Furthermore, it has been reported that chronic administration of both nicotine and SIB1765F, but not AR-R17779, resulted in an enhanced locomotor response to acute challenge with either nicotine or SIB1765F but not AR-R17779, suggesting that the $\alpha 4 \beta 2$ subtype plays a role in both the initiation and expression of sensitization to the psychomotor stimulant effects of nicotine [107]. Moreover, administration of ARR17779 improved learning in two radial-arm maze tasks and reversed working memory impairment caused by fimbriafornix section [108]. These findings suggest that $\alpha 7 \mathrm{nAChRs}$ play a role in learning and memory, and that agonists of $\alpha 7$ nAChRs might have therapeutic potential for cognitive impairments in neuropsychiatric diseases, including schizophrenia.

Very recently, researchers at AstraZeneca reported that a furopyridine, $\left(2^{\prime} R\right)$-spiro-[1-azabicyclo[2.2.2] octane-3, $2^{\prime}\left(3^{\prime} H\right)$ furo[2,3-b]pyridine D-tartrate (AZD0328; Fig. 4), was a novel selective partial agonist for an $\alpha 7 \mathrm{nAChR}$ [109]. AZD0328 exhibited high affinity for the native rat $(K \mathrm{i}=4.7$ $\mathrm{nM})$ and recombinant human $(K \mathrm{i}=3.0 \mathrm{nM}) \alpha 7 \mathrm{nAChR}$, respectively. ADZ0328 also exhibited high affinity for both native rat $(K \mathrm{i}=25 \mathrm{nM})$ and recombinant human $(K \mathrm{i}=12 \mathrm{nM})$ $5-\mathrm{HT}_{3}$ receptors. In contrast, AZD0328 exhibited only moderate affinity for the $\alpha 4 \beta 2 \mathrm{nAChR}$ of the native rat $(K \mathrm{i}=140 \mathrm{nM})$ and very low affinity for the "ganglionic" $\alpha 3$ subunit-containing $(K \mathrm{i}=2,500 \mathrm{nM})$ and muscle $\alpha 1 \beta 1 \gamma \delta$ nAChR $(K \mathrm{i}=20,000)$ of the mouse. Functional assay revealed the partial agonistic nature of AZD0328. The half maximal $(50 \%)$ effective concentration $\left(\mathrm{EC}_{50}\right)$ and intrinsic activity of AZD0328 were $150 \mathrm{nM}$ and $61 \%$ for rat $\alpha 7 \mathrm{nAChR}$ and 338 $\mathrm{nM}$ and $65 \%$ for human $\alpha 7 \mathrm{nAChR}$, respectively. Administration of a low dose $(0.00138 \mathrm{mg} / \mathrm{kg})$ of AZD0328 in vivo leads to a significant increase in the excitability of midbrain dopaminergic neurons with no independent change in the spike patterns produced by these neurons. Within the same dose range, AZD0328 led to a significant increase in cortical dopamine release and improved both conditioned response learning and memory retention in an object recognition task. These effects were blocked by the selective $\alpha 7 \mathrm{nAChR}$ antagonist MLA (Fig. 2). AZD0328 improved novel object recognition in mice over a broad range of doses $(0.00178-1.78 \mathrm{mg} / \mathrm{kg})$ and the compound effect was found to be absent in homozygous $\alpha 7 \mathrm{nAChR}$-knockout mice.

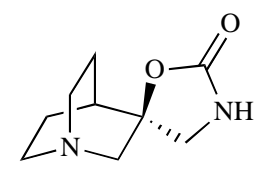

AR-R17779

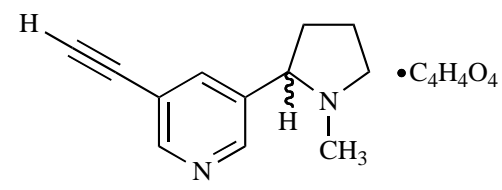

SIB $1765 \mathrm{~F}$

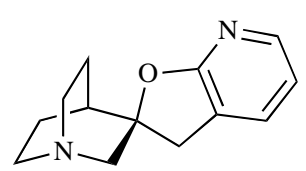

AZD0328

Fig. (4). Chemical structures of AR-R17779, SIB1765F, and AZD0328. 
Together, these data indicate that selective interaction with $\alpha 7$ nAChRs by AZD0328 selectively enhances midbrain dopaminergic neuronal activity, causing an enhancement of cortical dopamine levels; these neurochemical changes, in turn, likely underlie the positive behavioral responses observed in the two different animal models. These results also suggest that selective $\alpha 7 \mathrm{nAChR}$ agonists may have significant therapeutic utility in neurologic and psychiatric disorders in which cognitive effects and dopamine neuron dysfunction co-exist.

\section{Mitsubishi Tanabe}

Macor and $\mathrm{Wu}$ [110] reported some derivatives of 1azabicyclo[2.2.2] oct-3-yl phenylcarbamate as agonists of $\alpha 7$ nAChRs (Fig. 5). In order to develop novel agonists of $\alpha 7$ nAChRs, researchers at Mitsubishi Pharma Corporation (currently Mitsubishi Tanabe Pharma Corporation) hypothesized that 1-azabicyclo[2.2.2] octane derivatives, bearing an aromatic part and a spacer group at the 3-position, may exhibit agonist activity at $\alpha 7 \mathrm{nAChRs}$ [111]. By examining a series of 3-substituted 1-azabicyclo[2.2.2] octane derivatives, they found that (+)-3-[2-(benzo[b]thiophen-2-yl)-2-oxoethyl]-1- azabicycle[2.2.2] octane was a potent and partial agonist of $\alpha 7$ nAChRs (Fig. 5) [111]. Furthermore, they reported the structure-activity relationships and pharmacokinetic profiles of the series of compounds leading to the discovery of $(R)-3^{\prime}(5$-chlorothiophen-2-yl)spiro-1azabicyclo[2,2,2] octane-3,5'-[1',3'] oxazolidin- $2^{\prime}$-one (Fig. 5) [112]. This compound has potent binding affinity $(K \mathrm{i}=9 \mathrm{nM}$ for $\alpha 7 \mathrm{nAChRs}$ ) and good selectivity toward the other nicotinic subtypes $(\alpha 4 \beta 2$ and $\alpha 1 \beta 2 \gamma \delta)$. Also, this compound has good oral bioavailability and brain permeability. Interestingly, this compound $(10 \mathrm{mg} / \mathrm{kg}$, p.o.) significantly improved dizocilpine ( $3 \mathrm{mg} / \mathrm{kg}$ )-induced auditory gating deficits in rats, suggesting that this compound has the potential to improve sensory gating deficits in schizophrenic patients [112]. Moreover, they have developed a novel partial $\alpha 7$ nAChR agonist, W-56203, $(R)$-3'-(3-methylbenzo[b]thiophen-5-yl)spiro[1-azabicyclo[2.2.2] octane-3,5'-oxazolidin]-2'-one (Fig. 5) [113]. W-56203 bound to $\alpha 7 \mathrm{nAChRs}$ with a $K$ i value of $3 \mathrm{nM}$. No significant binding of W-56203
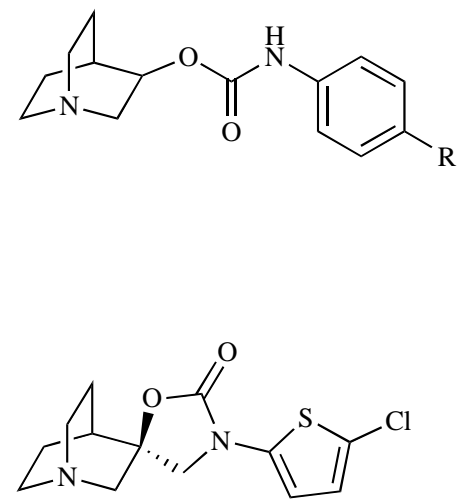

(R)-3'(5-chlorothiophen-2-yl)spiro-1azabicyclo[2.2.2] octane-3,5'-[1',3']oxazolidin-2'-one was detected at $\alpha 4 \beta 2 \mathrm{nAChRs}$ or muscarinic receptors. Furthermore, W-56203 showed no binding to other known receptors (dopamine $\mathrm{D}_{1}$ and $\mathrm{D}_{2}, 5-\mathrm{HT}_{1 \mathrm{~A}}, 5-\mathrm{HT}_{2}$, adrenergic $\alpha 1, \alpha 2$, histamine $\mathrm{H}_{1}$ and $\mathrm{H}_{2}$ ) or ion channels (NMDA and $\alpha$-amino-3-hydroxy-5-methyl-4-isoxazole propionic acid (AMPA)), although W-56203 exhibited a moderate affinity to $5-\mathrm{HT}_{3}$ receptors. In cultured hippocampal neurons, W56203 evoked a rapidly desensitizing inward current, which was blocked by the selective $\alpha 7 \mathrm{nAChR}$ antagonist MLA (1 $\mathrm{nM}$ ) (Fig. 2). Interestingly, W-56203 has been shown to significantly improve dizocilpine-induced auditory gating deficits in rats [113]. These results suggest that W-56203 is an orally active and partial agonist of $\alpha 7 \mathrm{nAChRs}$, and that W-56203 would be a potential drug for the treatment of schizophrenia.

\section{Targacept}

Researchers at Targacept Inc. reported that 2-(3-pyridyl)1-azabicyclo[3.2.2]nonane (TC-1698; Fig. 6) was a highly selective agonist of $\alpha 7 \mathrm{nAChRs}$ [114]. TC-1698 exhibited a $K \mathrm{i}$ of $11 \mathrm{nM}$ in the binding assay of $\left[{ }^{3} \mathrm{H}\right] \mathrm{MLA}$ to rat hippocampal membranes, whereas TC-1698 $(10 \mu \mathrm{M})$ had no or very low affinity for other receptors. TC-1698 exerts neuroprotective effects via activation of the JAK2/PI3K cascade, which can be neutralized through activation of the angiotensin II receptors [114]. These findings suggest that JAK2 plays a central role in the $\alpha 7 \mathrm{nAChR}$ activation of the JAK2-PI3K cascade in PC12 cells, which ultimately contribute to $\alpha 7 \mathrm{nAChR}$-mediated neuroprotection.

They further synthesized a series of 2-(arylmethyl)-3substituted quinuclidines as $\alpha 7 \mathrm{nAChR}$ agonists based on a putative pharmacophore model [115]. Quinuclidine is a well established pharmacophoric element. Its basic nitrogen, occupying a bridgehead position within an azabicyclic system, allocates the maximal electrostatic interaction combined with minimal steric demand. To further define pharmacophoric elements, they conducted virtual and synthetic diversification around a combination of 2-position and 3-position substitutions of the quinuclidine scaffold. This effort revealed the presence of three pharmacophoric elements: the cationic site (quinuclidine nitrogen), a

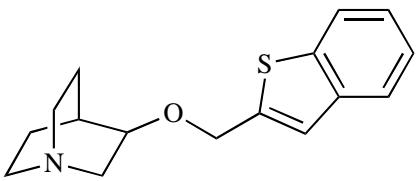

(+)-3-[2-(benzo[b]thiophen-2-yl)-2oxoethyl]-1-azabicyclo[2.2.2]octane

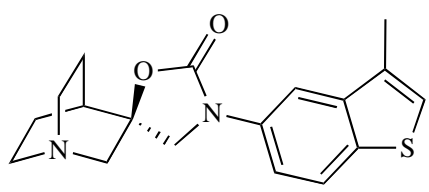

W-56203

Fig. (5). Chemical structures of 1-Azabicyclo[2.2.2] oct-3-yl phenylcarbamate derivatives, (+)-3-[2-(benzo[b]thiophen-2-yl)-2-oxoethyl]-1azabicycle[2.2.2] octane, $(R)-3^{\prime}$ (5-chlorothiophen-2-yl)spiro-1-azabicyclo[2,2,2]octane-3,5'-[1',3']oxazolidin-2'-one, and W-56203. 


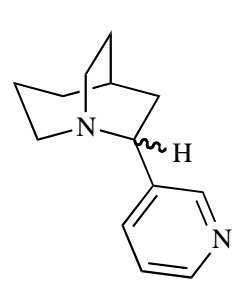

TC-1698

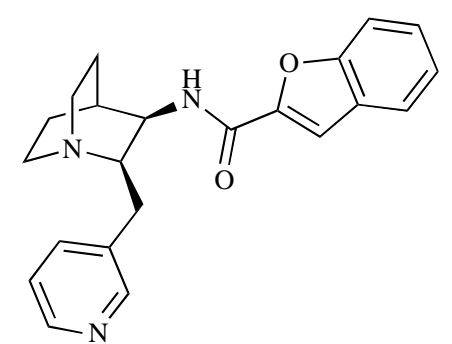

TC-5619
Fig. (6). Chemical structures of TC-1698 and TC-5619.

hydrogen bond acceptor at the 3-position, and another hydrogen bond acceptor at the 2-position (the pyridine ring). In position 2 of quinuclidine, heteroarylmethyl groups are favored over benzyl, and steric constraints restrict substitution on the heteroaryl (pyridine) ring. The pharmacophoric element in position 3 was most amenable to diversification, resulting in the generation of four classes of ligands: carbamates, ureas, amides and sulfonamide. Cisconfiguration is favorable for binding to the receptor. Within the 3-position substituent, a comparison of aliphatic and aromatic groups suggested that $\pi$-interaction may play a significant role in increasing affinity. As a result, several synthesized compounds exhibited high affinity to the $\alpha 7$ nAChR with $K \mathrm{i}$ values near or below $1 \mathrm{nM}$. None of these compounds bound to $\alpha 4 \beta 2$ receptors with any significant affinity $(K \mathrm{i}>10 \mu \mathrm{M})$. Among these series of compounds, $N$ $\{(2 R, 3 R)-2-[($ pyridin-3-yl)methyl]quinuclidin-3-yl $\}$ benzofuran-2-carboxamide (TC-5619; Fig. 6) has potent full agonistic activity for the $\alpha 7 \mathrm{nAChR}\left(\mathrm{EC}_{50}=33 \mathrm{nM}\right.$, agonist activity $=100$ ), at a concentration below those that result in desensitization. Hauser et al. [116] further characterized the pharmacological properties of TC-5619. TC-5619 binds with very high-affinity to the $\alpha 7 \mathrm{nAChR}$ of the native rat hippocampus $(K \mathrm{i}=1 \mathrm{nM})$ and the $\alpha 7 \mathrm{nAChR}$ of human HEK $\alpha 7 /$ RIC3 cells $(K \mathrm{i}=1 \mathrm{nM})$, respectively. TC-5619 has little or no activity at other nicotinic receptors, including the $\alpha 4 \beta 2$ ( $K \mathrm{i}=2,800$ and 2,100 $\mathrm{nM}$ for rat cortex and human SH-EP1 cells, respectively), ganglionic $(\alpha 3 \beta 4)$ and muscle subtypes. In a transgenic $t h(t k-) / t h(t k-)$ mouse model that reflects many of the developmental, anatomical, and multitransmitter biochemical aspects of schizophrenia, TC-5619 acted both alone and synergistically with the antipsychotic clozapine to correct impaired pre-pulse inhibition (PPI) and social behaviors which model positive and negative symptoms, respectively. Similar to the results in the transgenic mice, TC-5619 significantly reversed the apomorphine-induced PPI deficits in rats. In a novel objectrecognition paradigm in rats, TC-5619 demonstrated longlasting enhancement of memory over a wide dose range. These findings suggest that TC-5619, either alone or in combination with antipsychotics, could offer a new approach to treating the constellation of symptoms associated with schizophrenia, including cognitive dysfunction. A phase 1 single rising dose (10-900 mg) clinical trial of TC-5619 in 66 healthy volunteers showed that TC-5619 was generally well tolerated up to doses of $600 \mathrm{mg}^{*}$. A multiple dose

\footnotetext{
* Lippiello, P. TC-5619: An $\alpha 7$ nAChR selective agonist with efficacy in animal models of positive and negative symptoms, and cognitive dysfunction of schizophrenia.
}

(10-300 $\mathrm{mg}$ ) administered for 10 days in 38 young healthy volunteers achieved significant improvements in the clinical dementia rating (CDR) test. A phase 2 proof-of-concept study will start at 4Q 2009 in patients with AD and attention deficit hyperactivity disorder (ADHD).

\section{Pfizer}

Researchers at Pfizer reported on the selective $\alpha 7$ nAChR agonist PNU-282987, $N$-[(3R)-1-azabicyclo[2.2.2]oct-3-yl]-4-chlorobenzamide hydrochloride (Fig. 7) [117, 118]. PNU-282987 binds to $\alpha 7 \mathrm{nAChR}$ with a $K$ i of $27 \mathrm{nM}$, and showed evoked whole-cell currents from cultured rat hippocampal neurons that were sensitive to the selective $\alpha 7$ nAChR antagonist MLA $[117,118]$. Systemic administration of PNU-282987 (1 mg/kg, i.v.) significantly improved damphetamine-induced sensory gating deficits in chloral hydrate-anesthetized rats. These findings suggest that PNU282987 may be useful for treating the cognitive and attentional deficits of schizophrenia [117, 118]. This compound was later found, however, to possess significant human ether-a-go-go (hERG) potassium channel activity and thus did not meet Pfizer's criteria for further development. Additional work on this template demonstrated that fused 6,5-heterocyclic analogues, such as indole (Fig. 7), provided an avenue toward novel analogues with potential for improved safety profiles. Of the 6,5-fused heterocycles evaluated, $N$-[(3R)-1-azabicyclo[2.2.2]oct-3-yl]furo[2,3-c]pyridine-5-carboxamide (PHA-543613; Fig. 7) proved to be a potent, high-affinity agonist of the $\alpha 7 \mathrm{nAChR}(K \mathrm{i}=8.8 \mathrm{nM}$ : $\alpha 7-5-\mathrm{HT}_{3}$ chimera $\left.\mathrm{EC}_{50}=65 \mathrm{nM}\right)$ [119]. PHA-543613 possesses antagonist activity at the $5-\mathrm{HT}_{3}$ receptor $(K \mathrm{i}=628$ nM). PHA-543613 showed no detectable agonist activity $(>100 \mu \mathrm{M})$ and negligible antagonist activity at both musclelike nAChRs and ganglion-like nAChRs. Further, this furopyridine derivative did not significantly displace tritiated cytisine from rat brain homogenate at $1 \mu \mathrm{M}$, suggesting a selectivity over the $\alpha 4 \beta 2 \mathrm{nAChR}$. The excellent in vitro profile of PHA-543613 is matched by rapid brain penetration, high oral bioavailability in rats, and a favorable hERG profile. Furthermore, PHA-543613 demonstrated efficacy in two in vivo models, the reversal of an amphetamine-induced P50 gating deficit $(0.3 \mathrm{mg} / \mathrm{kg}$, i.v.), and improved performance in a novel object-recognition test (1.0 mg/kg, s.c.).

While further evaluation of PHA-543613 was underway, researchers at Pfizer identified additional novel, potent $(<50$ $\mathrm{nM}$ ), and selective $\alpha 7 \mathrm{nAChR}$ agonists that, like PHA543613 , possess reduced hERG activity and low first pass metabolism [120]. To expand the SAR on the quinuclidine amide template and gain a broader understanding of the overlap with other nicotinic pharmacophores, two parallel approaches were utilized. The first focused on the acid portion of the quinuclidine template (amine part). The second approach investigated modifications to the azabicyclic ring system (acid part). The best compounds from each series are characterized by rapid brain penetration, good oral bioavailability in rats, and in vivo efficacy in a rat P50 auditory sensory gating assay. Finally, the researchhers discovered 2,3-dihydro- $N$ - $[(R)$-quinuclidin-3-yl]benzo[b]-

Nicotinic acetylcholine receptors as therapeutic targets: emerging frontiers in basic research and clinical science; Chicago, IL, Oct. 14-Oct. 17, 2009. 
<smiles>O=C(N[C@H]1CN2CCC1CC2)c1ccc(Cl)cc1</smiles>

PNU-282987<smiles>O=C(N[C@H]1CN2CCC1CC2)c1cc2ccoc2cn1</smiles>

PHA-543613<smiles>O=C(N[C@H]1CN2CCC1CC2)c1ccc2cc[nH]c2c1</smiles>

$N$-[(R)-quinuclidin-3-yl]-1H-indole-6-carboxamide<smiles>O=C(N[C@H]1CN2CCC1CC2)c1ccc2c(c1)OCCO2</smiles>

PHA-568487

Fig. (7). Chemical structures of PNU-282987, $N$-[(R)-quinuclidin-3-yl]-1H-indole-6-carboxamide, PHA-543613, and PHA-568487.

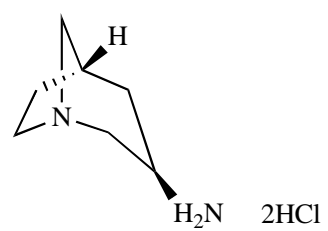

$(3 R, 5 R)$-1-aza-bicyclo[3.2.1]octan-3amine dihydrochloride<smiles>O=C(N[C@@H]1C[C@@H]2CCN(C2)C1)c1ccc(Cl)cc1</smiles><smiles>O=C(Oc1ccc2ccccc2c1)N1CCN2CCC1CC2</smiles>

Compound 7aa<smiles>Cc1ccc2oc(N3CCN4CCC3CC4)nc2n1</smiles>

CP-810,123

Fig. (8). Chemical structures of (3R,5R)-1-aza-bicyclo[3.2.1] octan-3-amine dihydrochloride, para-chlorobenzamide derivatives of $(3 R, 5 R)$-1aza-bicyclo[3.2.1] octan-3-amine, PHA-709829, compound 7aa, and CP-801,123.

[1,4]dioxine-6-carboxamide (PHA-568487; Fig. 7), which showed an improved hERG safety profile over PHA-543613. However, these two phase, I clinical candidates (PHA543613 and PHA-568487) were discontinued due to cardiovascular findings. ${ }^{\dagger}$

Very recently, researchers at Pfizer disclosed the synthesis of $(3 R, 5 R)$-1-azabicyclo[3.2.1] octane-3-amine dihydrochloride (Fig. 8) and demonstrated that the activity of the corresponding para-chlorobenzamide (Fig. 8) in a $\alpha 7-5$ $\mathrm{HT}_{3}$ chimera assay was equal to that of the potent $\alpha 7 \mathrm{nAChR}$ agonist, PNU-282987. To identify novel, potent and orally bioavailable $\alpha 7 \mathrm{nAChR}$ agonists with in vitro and in vivo potential equal or better than that of PHA-543613, they proceeded to synthesis of an expanded set of amides derived from amine [121]. Among them, the furopyridine derivative

${ }^{\dagger}$ Rogers, B.N. Agonists of $\alpha 7 \mathrm{nAChRs}$ for the potential treatment of cognitive deficits in Schizophrenia. Nicotinic acetylcholine receptors as therapeutic targets: emerging frontiers in basic research and clinical sciences; San Diego, CA, Oct. 31-Nov. 2, 2007.
$N$-[(3R,5R)-1-aza-bicyclo[3.2.1]octan-3-yl]furo[2,3-c]pyridine-5-carboxamide (PHA-709829; Fig. 8), which is a structurally similar analog of PHA-543613, showed very similar activity in the $\alpha 7-5-\mathrm{HT}_{3}$ chimera functional assay $\left(\mathrm{EC}_{50}=81 \mathrm{nM}\right)$ and similar affinity in the $\alpha 7$ binding assay $(K \mathrm{i}=2.9$ and 3.9). PHA-709829 showed stability in rat liver microsomes comparable to that of PHA-543613. PHA709829 showed excellent CNS penetration in a brain delivery assessment screen (MDCK cell permeability, mouse brain/plasma ratio, Pgp substrate), displaying a profile very similar to PHA-543613.

Researchers at Pfizer also identified 1,4diazabicyclo[3.2.2]nonane phenyl carbamate (compound 7aa; Fig. 8) as subtype selective, high affinity $\alpha 7$ agonist $(K \mathrm{i}=23 \mathrm{nM}$, agonist activity $=175 \%)$. The pharmacological profiles of this compound closely resembled that of 4-bromophenyl 1,4-diazabicyclo[3.2.2]nonane-4-carboxylate hydrochloride (SSR180711; Fig. 9). The advantage of 
compound 7aa was that it showed the potential for an improved cardiosafety profile due to its low affinity for hERG.

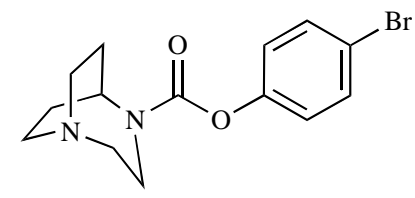

SSR180711

Fig. (9). Chemical structure of SSR180711.

Very recently, they reported the benzoxyazole derivative 2-(5-methyloxazolo[4,5-b]pyridin-2-yl)-2,5-diaza-bicyclo[3. 2.2]nonane (CP-810,123; Fig. 8) as a novel $\alpha 7 \mathrm{nAChR}$ agonist. ${ }^{\ddagger}$ This compound showed low affinity for hERG $\left(\mathrm{IC}_{50}=40,000 \mathrm{nM}\right)$ and high affinity binding to $\alpha 7 \mathrm{nAChR}$. CP-810,123 has an excellent brain penetration and slow clearance from plasma and has shown marked ex vivo binding to cerebral binding sites $\left(\mathrm{ED}_{50}=0.34 \mathrm{mg} / \mathrm{kg}\right)$. $\mathrm{CP}$ 810,123 also showed favorable preclinical findings in a number of animal models of cognition and was therefore advanced into clinical trials. However, the multiple-dose, 14day clinical trial of $\mathrm{CP}-810,123$ did not achieve any improvement of cognition at any of the doses tested, and was discontinued due to the occurrence of non-sustained ventricular tachycardia.

\section{Sanofi-Aventis}

Researchers at Sanofi-Aventis demonstrated a novel $\alpha 7$ nAChR agonist, SSR180711, 4-bromophenyl 1,4diazabicyclo[3.2.2]nonane-4-carboxylate hydrochloride (Fig. 9) [122]. Binding assays show that SSR180711 has a high and selective affinity for the human $(K \mathrm{i}=14 \mathrm{nM})$ and rat $(K \mathrm{i}=22 \mathrm{nM}) \alpha 7 \mathrm{nAChRs}$. This ligand inhibits, in a dosedependent manner, the ex vivo $\left[{ }^{3} \mathrm{H}\right] \alpha$-bungarotoxin binding in mouse cortical homogenates after both i.p. and p.o. administration. At recombinant human $\alpha 7$ nAChRs, SSR180711 displays a partial agonist profile. Furthermore, it has been reported that SSR180711 improves cognitive deficits in a variety of rat models related to schizophrenia [123]. This drug restores the selective attention deficit induced by phencyclidine (PCP) administration at the neonatal stage. This action is reversed by the $\alpha 7 \mathrm{nAChR}$ antagonist MLA. This drug also restores a short-term episodic memory impairment and a spatial working memory deficit induced by PCP or dizocilpine.

Hashimoto et al. [124] reported that repeated administration of PCP significantly decreased the density of $\alpha 7 \mathrm{nAChRs}$ in the mouse brain. In addition, Hashimoto et al. [124] reported that SSR180711 could ameliorate cognitive deficits in mice after repeated administration of PCP, and that these effects could be blocked by the co-administration of MLA. Furthermore, Thomsen et al. [125] reported that repeated co-administration of SSR180711 (3 mg/kg) with PCP prevented both changes of parvalbumin and

${ }^{\ddagger}$ O’Donnell, C.J. CP-810,123 a third generation alpha-7 nAChR agonist for treatment of cognitive deficits associated with schizophrenia. Nicotinic acetylcholine receptors as therapeutic targets: emerging frontiers in basic research and clinical science; Chicago, IL, Oct. 14-Oct. 17, 2009. synaptophysin, which correspond to changes seen in patients with schizophrenia, and changes in the level of Arc, a molecule involved in synaptic plasticity, mRNA expression in the prefrontal cortex, and the behavioral impairment induced by PCP. Moreover, Barak et al. [126] reported that SSR180711 potentiated latent inhibition (LI) in normal rats and reversed amphetamine-induced LI disruption, two models considered predictive of activity against positive symptoms of schizophrenia [127, 128]. It was also reported that increase of expression of immediate early genes in the frontal cortex and nucleus accumbens has been demonstrated after administration with SSR180711 [129, 130]. Søderman et al. [131] reported that acute systemic administration of SSR180711 (10 mg/kg) resulted in a significant increase in Fos protein levels in the shell of the nucleus accumbens in wild-type mice, but had no effect in the $A \beta_{1-42}$ overexpressing transgenic mice. This result suggests that overexpression of human $\mathrm{A} \beta$ peptides inhibits $\alpha 7 \mathrm{nAChR}$ dependent neurotransmission in vivo, perhaps via direct interaction with $\alpha 7 \mathrm{nAChR}$, and underscores that clinical trials testing $\alpha 7 \mathrm{nAChR}$ agonists should be related to the content of $A \beta$ peptides in the patient's nervous system.

Taken together, these findings suggest that SSR180711 has the potential to improve cognitive deficits associated with schizophrenia and AD.

\section{WYETH/SIENA BIOTECH}

Based on an initial hit identified in a screening program, researchers at Wyeth Research and Siena Biotech SpA obtained a novel $\alpha 7$ nicotinic acetylcholine receptor agonist, 5-morpholino-4-yl-pentanoic acid (4-pyridn-3-yl-phenyl)amide (SEN12333/WAY-317538; Fig. 10), as the result of a structure-activity relationship study [132]. SEN12333/WAY317538 shows high affinity for the rat $\alpha 7$ receptor expressed in $\mathrm{GH} 4 \mathrm{C} 1$ cells $(\mathrm{Ki}=260 \mathrm{nM})$ and acts as a full agonist in functional $\mathrm{Ca}^{2+}$ flux studies $\left(\mathrm{EC}_{50}=1.6 \mu \mathrm{M}\right)$. SEN12333/WAY-317538 did not show agonist activity at the other nicotinic receptor subtypes tested ( $\alpha 1$ and $\alpha 4 \beta 2)$ or at highly homologous receptors $\left(5-\mathrm{HT}_{3 \mathrm{~A}}\right)$. SEN12333/WAY 317538 acted as a weak antagonist at $\alpha 3$-containing receptors and histamine $\mathrm{H}_{3}$ receptors. At a concentration of $10 \mu \mathrm{M}$ of SEN12333/WAY-317538, no detectable inhibition binding was measured for the neurotransmitter and bioactive peptide receptors. SEN12333/WAY-317538 also showed minimal hERG inhibition, and desirable drug-like (molecular weight, number of rotatable bonds, $\log P$, polar surface area) and pharmacokinetic properties. In vivo, SEN12333/WAY317538 treatment ( $3 \mathrm{mg} / \mathrm{kg}$ i.p.) improved episodic memory in a novel object-recognition task in rats under the conditions of spontaneous forgetting and cognitive disruptions induced via glutamatergic (dizocilpine) or cholinergic (scopolamine) mechanisms [133]. This improvement was blocked by the $\alpha 7$ nAChR antagonist MLA. SEN12333/WAY-317538 also prevented a scopolamine-induced deficit in a passive avoidance task. In models targeting other cognitive domains, including attention and perceptual processing, SEN12333/WAY-317538 normalized the apomorphine-induced deficit of PPI. Neuroprotection of SEN12333/WAY-317538 was demonstrated in quisqualate-lesioned animals in which treatment with SEN12333/WAY-317538 (3 mg/kg/day i.p.) resulted in a significant protection of choline acetyltransferase-positive neurons in the lesioned 
<smiles>O=C(CCCCN1CCOCC1)Nc1ccc(-c2cccnc2)cc1</smiles>

SEN12333/WAY-317538

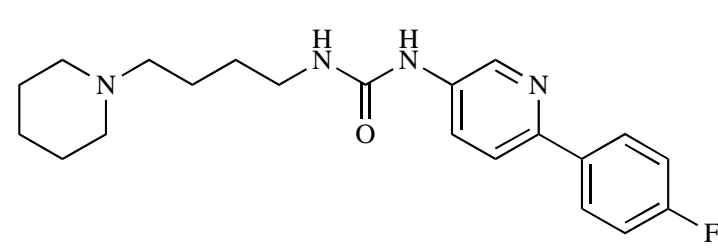

WYE-103914/SEN34625

Fig. (10). Chemical structures of SEN12333/WAY-317538 and WYE-103914/SEN34625.

hemisphere. Cumulatively, these results demonstrate that the novel $\alpha 7$ nAChR agonist SEN12333/WAY-317538 has precognitive and neuroprotective properties.

Very recently, researchers at Wyeth reported the novel selective $\alpha 7$ nAChR agonist 1-[6-(4-fluorophenyl)pyridin-3yl]-3-[4-(piperidin-1-yl)butyl]urea (WYE-103914/SEN34625; Fig. 10). WYE-103914/SEN34625 bound with high affinity to a rat $\alpha 7 \mathrm{nAChR}$ expressed in GH4C1 cells with a $K \mathrm{i}$ of $44 \mathrm{nM}$ and increased intracellular $\mathrm{Ca}^{2+}$ with an $\mathrm{EC}_{50}$ of $130 \mathrm{nM}$ (activity=99\%). WYE-103914/SEN34625 was $>100$-fold selective against $\alpha 1, \alpha 3, \alpha 4 / \beta 2$ nAChRs receptors and the $5-\mathrm{HT}_{3}$ receptor. In a rat novel object-recognition procedure, WYE-103914/SEN34625 (1 mg/kg, p.o.) treatment produced statistically significant enhancement of visual learning and memory retention, and this effect was blocked by pretreatment with MLA (5 mg/kg, i.p.). Pretreatment with WYE-103914/SEN34625 reversed the memory disrupting effects of dizocilpine $(10 \mathrm{mg} / \mathrm{kg}$, p.o.) in rats. WYE-103914/SEN34625, administered concurrently with dizocilpine immediately after training, produced a statistically significant reversal of dizocilpine-disrupted social odor recognition in mice at $3 \mathrm{mg} / \mathrm{kg}$, p.o. In addition, WYE-103914/SEN34625 administered immediately following training enhanced retention memory in social odor recognition evaluated 6 days later $(10 \mathrm{mg} / \mathrm{kg}$, p.o. $)$. Treatment with $3 \mathrm{mg} / \mathrm{kg} /$ day i.p. of WYE-103914/SEN34625 for 7 days also attenuated the decrease in the number of choline acetyltransferase-positive neurons produced by the injection of quisqualic acid into the nucleus basalis magnocellularis. These data indicate that WYE-103914/ SEN34625 exhibits a robust preclinical cognitive-enhancing and potentially neuroprotective profile.

\section{Bayer}

Researchers at Bayer reported the profile of the novel $\alpha 7$ nAChR agonist $N$-[(3R)-1-azabicyclo[2.2.2] oct-3-yl]-7-[2(methoxy)phenyl]-1-benzofuran-2-carboxamide (ABBF; Fig. 11) [134]. ABBF bound to $\alpha 7 \mathrm{nAChR}$ in rat brain membranes $(K \mathrm{i}=62 \mathrm{nM})$ and to recombinant $5-\mathrm{HT}_{3}$ receptors $(K \mathrm{i}=60 \mathrm{nM})$, and thus its agonistic activity was approximately 50-fold more potent than that of the natural agonist $\mathrm{ACh}(K \mathrm{i}=3 \mu \mathrm{M})$ and 10 -fold more potent than nicotine $(K \mathrm{i}=770 \mathrm{nM})$. ABBF was a potent agonist at the recombinant rat and human $\alpha 7 \mathrm{nAChR}$ expressed in Xenopus oocytes, but it did not show agonist activity at other nAChR subtypes.

\footnotetext{
$\S$ Dunlop, J.; Comery, T.A.; Lock, T.; Kramer, A.; Kowal, D.; Yeola, S.; Jow, F.; Aschmies, S.; Lin, Q.; Beyer, C.E.; Brennan, J.; Kelly, C.; Roncarati, R.; Scali, C.; Haydar, S.; Ghiron, C.; Marquis, K.L.; Harrison, B.; Robichaud, A.; Terstappen, G.C. In vitro pharmacological characterization and pro-cognitive effects of the selective alpha-7 nicotinic agonist WYE-103914. Biochem. Pharmacol., 2009, 78, 911.
}

$\mathrm{ABBF}$ acted as an antagonist of the $5-\mathrm{HT}_{3}$ receptor and $\alpha 3 \beta 4, \alpha 4 \beta 2$, and muscle nAChRs. ABBF improved social recognition memory in rats $(0.3-1 \mathrm{mg} / \mathrm{kg}$, p.o.). This improvement was blocked by intracerebroventricular administration of the $\alpha 7 \mathrm{nAChR}$ antagonist MLA $(10 \mu \mathrm{g})$. In addition, ABBF improved the working memory of aged rats in a water maze repeated acquisition paradigm $(1 \mathrm{mg} / \mathrm{kg}$, p.o.) and object-recognition memory in mice $(0.3-1 \mathrm{mg} / \mathrm{kg}$, p.o.). Moreover, rats trained to discriminate nicotine $(0.4$ $\mathrm{mg} / \mathrm{kg}$, s.c.) from vehicle did not generalize to $\mathrm{ABBF}$ $(0.3-30 \mathrm{mg} / \mathrm{kg}$, p.o.), suggesting that the nicotine cue is not mediated by the $\alpha 7 \mathrm{nAChRs}$ and that selective $\alpha 7 \mathrm{nAChR}$ agonists may not share the abuse liability of nicotine. These results support the hypothesis that $\alpha 7 \mathrm{nAChR}$ agonists might provide a novel therapeutic strategy for the treatment of cognitive deficits with low abuse potential.

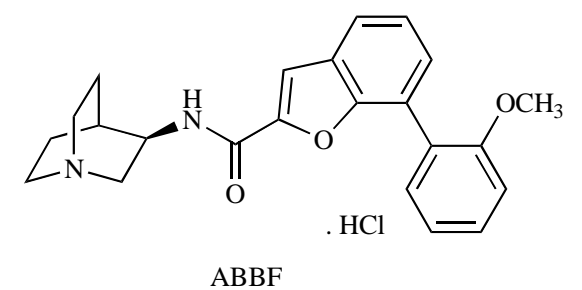

Fig. (11). Chemical structure of ABBF.

\section{Abott Laboratories}

As mentioned above, the most recently described $\alpha 7$ agonists are derived from the quinuclidine structural class. Alternatively, researchers at Abott Laboratories identified 2,7-bis(2-(diethylamino)ethoxy)-9H-fluoren-9-one (Tilorone; Fig. 12) as a lead structure for a novel $\alpha 7$-selective agonist and developed related tricyclic analogs [135]. The lead structure tilorone bound $\alpha 7 \mathrm{nAChR}\left(\mathrm{IC}_{50}=110 \mathrm{nM}\right)$ with high selectivity relative to $\alpha 4 \beta 2\left(\mathrm{IC}_{50}=70,000 \mathrm{nM}\right)$, activated human $\alpha 7 \mathrm{nAChR}$ with an $\mathrm{EC}_{50}$ value of $2.5 \mu \mathrm{M}$ and maximal response of $67 \%$ relative to $\mathrm{ACh}$, and showed little agonist effect at human $\alpha 3 \beta 4$ or $\alpha 4 \beta 2$ nAChRs. However, the rat $\alpha 7 \mathrm{nAChR}$ maximal response was only $34 \%$. Lead optimization led to 2-(5-methyl-hexahydro-pyrrolo[3,4c]pyrrol-2-yl)-xanthen-9-one (A-844606; Fig. 12) with improved binding $\left(\alpha 7: \mathrm{IC}_{50}=11 \mathrm{nM} ; \alpha 4 \beta 2\right.$ : $\left.\mathrm{IC}_{50}>30,000 \mathrm{nM}\right)$ and activity at both human and rat $\alpha 7 \mathrm{nAChRs}\left(\mathrm{EC}_{50} \mathrm{~s}=1.4\right.$ and $2.2 \mu \mathrm{M}$, respectively; apparent efficacies $=61 \%$ and $63 \%$ ). These compounds also activated native $\alpha 7 \mathrm{nAChR}$, stimulating extracellular signal-regulated kinase $1 / 2$ (ERK1/2) phosphorylation in PC12 cells. These findings suggest that tilorone, known as an interferon inducer, is a selective $\alpha 7$ nAChR agonist, and that the fluorene 


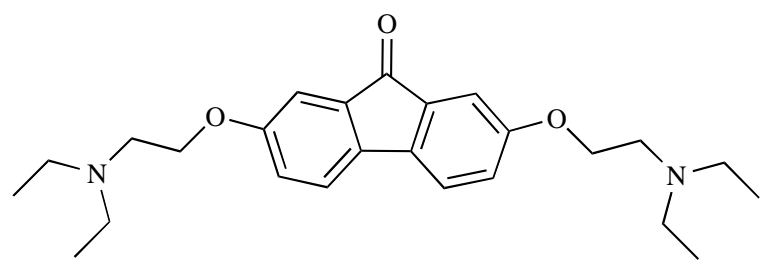

Tilorone

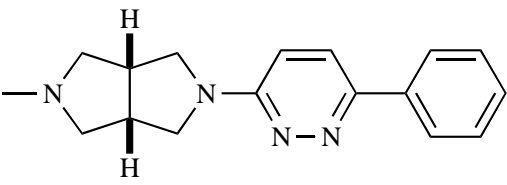

A-582941

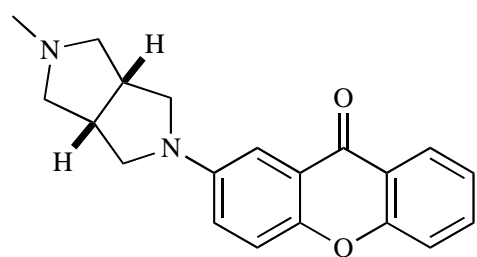

A- 844606

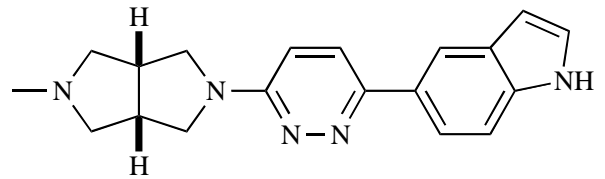

Compound 46

Fig. (12). Chemical structure of Tilorone, A-844606, A-582941, and compound 46.

pharmacophore would be useful for the development of selective $\alpha 7$ nAChR agonists. Whether $\alpha 7$ nAChR stimulation mediates interferon induction, or whether interferon induction may influence the potential antiinflammatory properties of $\alpha 7 \mathrm{nAChR}$ agonists remains to be elucidated.

Researchers at Abbott Laboratories also reported a novel biaryl diamine $\alpha 7$ nAChR agonist, 2-methyl-5-(6phenylpyridazin-3-yl)octahydropyrrolo[3,4-c]pyrrole (A582941; Fig. 12). A-582941 was found to exhibit highaffinity binding to native rat $(K \mathrm{i}=10.8 \mathrm{nM})$ and human $(K \mathrm{i}=16.7 \mathrm{nM}) \alpha 7 \mathrm{nAChRs}[136,137]$. In contrast, A-582941 showed substantially weaker binding $(K \mathrm{i}>100 \mu \mathrm{M})$ to $\alpha 4$, $\alpha 3$, and $\alpha 1$ subunit-containing nAChRs, respectively. Furthermore, A-582941 $(10 \mu \mathrm{M})$ did not show significant displacement of binding of $>75$ targets (multiple G-proteincoupled receptors, ligand- and voltage-gated ion channel binding sites, acetylcholine esterase, and muscarinic receptors) with the exception of $5-\mathrm{HT}_{3}$ receptors ( $\mathrm{Ki}=154$ nM). A-582941 showed partial agonism at Xenopus oocytes expressing human $\alpha 7 \quad \mathrm{nAChRs} \quad\left(\mathrm{EC}_{50}=4.26 \mu \mathrm{M}\right.$; activity $=52 \%$ ) [137]. A-582941 showed acceptable pharmacokinetic properties and excellent distribution to the CNS in rodents. For example, intraperitoneal (i.p.) administration of A-582941 (1 $\mu \mathrm{mol} / \mathrm{kg})$ in mice produced maximal levels in the brain $(286 \mathrm{ng} / \mathrm{g}$ at $0.33 \mathrm{~h})$ that were 11-fold higher than the maximum plasma concentration (26 $\mathrm{ng} / \mathrm{mL}$ at $0.25 \mathrm{~h}$ ). This distribution ratio was maintained over an $8 \mathrm{~h}$ period, as the drug cleared from the brain and plasma with $t_{1 / 2}=2.5-3.2 \mathrm{~h}$. Similarly, in rats, A-582941 distributes with approximately 6-fold higher levels in the brain than the plasma after i.p. dosing at $2-20 \mu \mathrm{mol} / \mathrm{kg}$. Over this dose range, linear pharmacokinetics were observed, with the brain $\mathrm{C}_{\max }$ (normalized to a $1 \mu \mathrm{mol} / \mathrm{kg}$ dose) averaging $363 \mathrm{ng} / \mathrm{g}$ and maximum plasma levels of $62 \mathrm{ng} / \mathrm{mL}$. A-582941 enhanced cognitive performance in behavioral assays including the monkey delayed matching-to-sample, rat social recognition, and mouse inhibitory avoidance models, which capture domains of working memory, short-term recognition memory, and long-term memory consolidation, respectively. In addition, A-582941 normalized the sensory gating deficits induced by the $\alpha 7 \mathrm{nAChR}$ antagonist MLA in rats, and in $\mathrm{DBA} / 2$ mice that exhibit a natural sensory gating deficit. In vitro and in vivo studies indicated that A-582941 activates signaling pathways known to be involved in cognitive functions such as ERK1/2 and cAMP response elementbinding protein (CREB) phosphorylation [137]. A-582941 exhibited a benign secondary pharmacodynamic and tolerability profile as assessed in a battery of assays of cardiovascular, gastrointestinal, and CNS function. A582941 was non-mutagenic in the Ames reverse mutation assay in 5 bacterial strains, even with metabolic activation by a microsomal S9 fraction. The predominant adverse effects of A-582941, observed at doses substantially greater than those shown to be effective in cognition models, include clinical signs of CNS activity (tremors). Emesis and cardiovascular effects are of relatively minor concern. Although moderate QTc prolongation is observed with A582941 in dogs at high plasma exposures, it does not appear to be $\alpha 7$-related. Investigation of potential carcinogenic effects produced no significant findings to suggest any $\alpha 7$ related toxicity. The details of the preclinical validation studies of A-582941 were recently reported [138]. Very recently, Biter et al. [139] reported that A-582941 can lead to increased phosphorylation of the inhibitory regulating amino acid residue Ser-9 on the glycogen synthase kinase $3 \beta$ (GSK3 $\beta$ ), a major kinase responsible for tau hyperphosphorylation in the neuropathology of tauopathies such as front-temporal dementia and AD. A-582941 increased Ser-9 phosphorylation of GSK3 $\beta$ in the mouse cingulate cortex and hippocampus, and this increase in phosphorylation was not observed in $\alpha 7 \mathrm{nAChR}$-knockout mice. Moreover, A-582941 continuous infusion decreased the phosphorylation of tau in hippocampal CA3 mossy fibers and spinal motoneurons in a hypothermia-induced tau hyperphosphorylation mouse and AD double transgenic APP/tau mouse model, respectively.

Very recently, researchers at Abbott Laboratories reported a series of 5-(pyridine-3-yl)octahydropyrrolo[3,4$c$ pyrroles as a diamine scaffold for constitution of either $\alpha 4 \beta 2$ or $\alpha 7$ selective nAChR ligands [140]. In that article, they identified the most potent (agonist activity=87\%) and 
selective ( $K \mathrm{i}$ for $\alpha 7=0.24 \mathrm{nM}$; $>400,000$-fold selective for $\alpha 4 \beta 2) \quad \alpha 7$ ligand in this series as 5-\{6-[(3aS,6aR)hexahydro-5-methylpyrrolo[3,4-c]pyrrol-2(1H)-yl]pyridazin3-yl $-1 H$-indole (compound 46; Fig. 12).

\section{Novartis}

Researchers at Novartis reported a novel selective $\alpha 7$ nAChR agonist, (S)-(1-azabicyclo[2.2.2]oct-3-yl)-carbamic acid (S)-1-(2-fluoro-phenyl)-ethyl ester (JN403; Fig. 13) [141]. JN403 displayed high affinity for human recombinant $\alpha 7 \mathrm{nAChR}(\mathrm{Ki}=200 \mathrm{nM}) . K \mathrm{i}$ values were estimated from the original $\mathrm{pKD}$ data. JN403 showed lower affinity for two other recombinant $\mathrm{nAChR}$ subtypes, human $\alpha 3 \beta 4(\mathrm{Ki}=6,309$ $\mathrm{nM})$ and human $\alpha 4 \beta 2(\mathrm{Ki}=158,489 \mathrm{nM})$. JN403 also showed low affinity toward the native murine $5-\mathrm{HT}_{3}$ receptor $(K \mathrm{i}=12,589 \mathrm{nM})$. Further, JN403 showed selectivity over a wide range of neurotransmitter receptors, ion channels and transporters. A functional assay with Xenopus oocytes expressing human recombinant $\alpha 7 \mathrm{nAChR}$ showed the partial agonistic nature of $\mathrm{JN} 403\left(\mathrm{EC}_{50}=2.14 \mu \mathrm{M}\right.$; agonist activity $=55 \%$ ).

Recently, in vivo effects of JN403 were reported by researchers at Novartis [142]. JN403 rapidly penetrates into the brain after intravenous (i.v.) and after peroral (p.o.) administration in mice and rats. In the social recognition test in mice JN403 facilitates learning/memory performance over a broad dose range. JN403 shows anxiolytic-like properties in the social exploration model in rats and the effects are retained after a $6 \mathrm{~h}$ pre-treatment period and after subchronic administration. Systemic administration of JN403 restores sensory gating in DBA/2 mice, a strain with reduced sensory inhibition under standard experimental conditions. Furthermore, JN403 shows anticonvulsant potential in the audiogenic seizure paradigm in $\mathrm{DBA} / 2$ mice. In the two models of permanent pain tested, JN403 produces a significant reversal of mechanical hyperalegesia. Together, these data suggest that JN403 may be beneficial for improving learning/memory performance, restoring sensory gating deficits, and alleviating pain, epileptic seizures and conditions of anxiety.

The common pharmacophore of nicotine and $\alpha 7 \mathrm{nAChR}$ agonists usually consists of a strong base (e.g., pyrolidine in nicotine; piperidine or tetrahydropyridine in an anabasein- derived scaffold; or a bicyclic amine, usually quinuclidine) connected to a hydrophilic element by a linker (e.g., carbamate, ether or amide). In view of the highly populated chemical space around these general scaffolds, researchers at Novartis discovered alternative templates. They found a cis $\gamma$-lactam scaffold and optimized it to reveal highly potent and selective $\alpha 7 \mathrm{nAChR}$ agonists with in vitro activity and selectivity and with good brain penetration in mice [143]. Among them, (3R,5S)-1-methyl-5-(2-phenylethynyl)-3[(piperidin-1-yl)methyl]pyrrolidin-2-one (compound 28) and $(3 R, 5 S)-5$-[2-(benzofuran-5-yl)ethynyl]-1-methyl-3-[(piperidin-1-yl)methyl]pyrrolidin-2-one (compound 30) showed potent and selective $\alpha 7 \mathrm{nAChR}$ agonistic activity (Fig. 13). Compounds 28 and 30 displayed high affinity for human recombinant $\alpha 7 \mathrm{nAChR}$ ( $\mathrm{IC}_{50}=10$ and $7.9 \mathrm{nM}$, respectively). The $\mathrm{IC}_{50}$ values were estimated from the original $\mathrm{pIC}_{50}$ data. At other recombinant $\mathrm{nAChR}$ subtypes, compounds 28 and 30 showed lower affinity: human $\alpha 3 \beta 4\left(\mathrm{IC}_{50}=1,258.9\right.$ and $1,000 \mathrm{nM}$, respectively); human $\alpha 4 \beta 2\left(\mathrm{IC}_{50}=7,943.3\right.$ and $10,000 \mathrm{nM}$, respectively); human $\alpha 1 \beta 1 \gamma \delta\left(\mathrm{IC}_{50}=12,589.3\right.$ and 6,309.6 nM, respectively). Compounds 28 and 30 also showed low affinity toward recombinant human $5-\mathrm{HT}_{3}$ receptors $\left(\mathrm{IC}_{50}=251,188.6\right.$ and $50,118.7 \mathrm{nM}$, respectively). When tested against human recombinant muscarinic receptors, compounds 28 and 30 also displayed an $\mathrm{IC}_{50}>10$ $\mu \mathrm{M}$ on all subtypes (M1-M5). Compound 28 showed rapid clearance, but the brain/plasma ratios remained high at 1 and $4 \mathrm{~h}$ after treatment with $30 \mu \mathrm{mol} / \mathrm{kg}$ p.o.. Compound 30 improved the in vivo pharmacokinetic properties. High brain and plasma levels were observed at 1 and $4 \mathrm{~h}$ following administration. Additionally, these compounds displayed good cardiosafety profiles. Taken together, these findings indicate that these new scaffolds, which are devoid of the classical bicyclic amine, will provide a valuable lead series for further development.

\section{Eli Lilly}

Researchers at Eli Lilly found several high affinity ligands for $\alpha 7 \mathrm{nAChRs}$ with no/small 5- $\mathrm{HT}_{3}$ receptor crossreactivity [144]. For example, $N$-(quinuclidin-3-yl)-5(thiophen-2-yl)thiophene-2-carboxamide (compound 8; Fig. 14) showed a potent $\alpha 7$ ligand $(K \mathrm{i}=1.1 \mathrm{nM})$ and still had 1,000-fold selectivity for $\alpha 7 \mathrm{nAChRs}$ over $5-\mathrm{HT}_{3}$ receptors. Additionally, 5-phenyl- $N$-[(R)-quinuclidin-3-yl] thiophene-2-

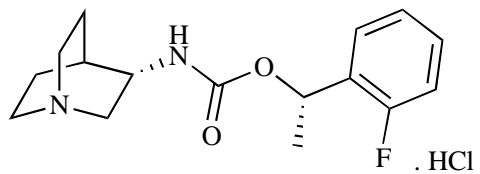

JN403

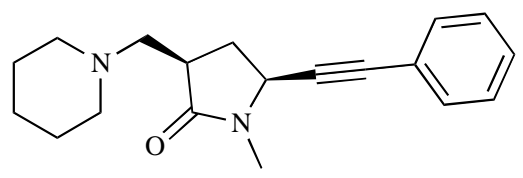

Compound 28

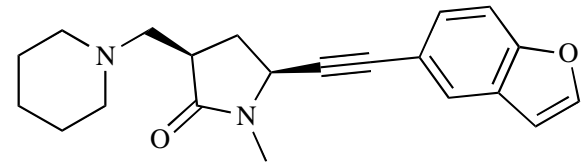

Compound 30

Fig. (13). Chemical structure of JN403, compound 28, and compound 30. 
carboxamide (compound 7a; Fig. 14) also showed a potent $\alpha 7$ ligand $(K \mathrm{i}=1.8 \mathrm{nM})$ and high selectivity for $\alpha 7 \mathrm{nAChRs}$ over $5-\mathrm{HT}_{3}$ receptors $\left(5-\mathrm{HT}_{3}\right.$ receptor $\mathrm{Ki}: 24 \%$ at $\left.10 \mu \mathrm{M}\right)$.

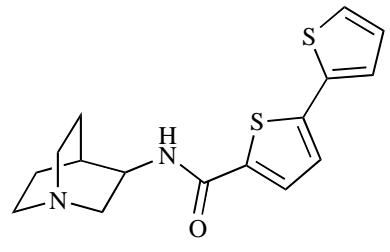

compound 8

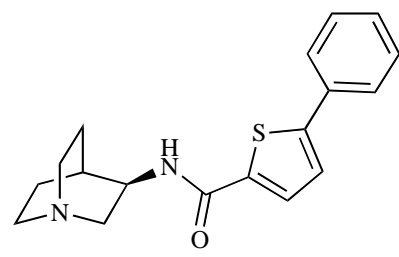

compound $7 \mathrm{a}$
Fig. (14). Chemical structure of compound 8 and compound $7 \mathrm{a}$.

\section{MEMORY PHARMACEUTICALS/ROCHE}

Researchers at Memory Pharmaceuticals reported a novel $\alpha 7 \mathrm{nAChR}$ partial agonist and $5-\mathrm{HT}_{3}$ receptor antagonist, R3487/MEM3454 [145]. The chemical structure of R3487/MEM3454 was not disclosed, and the compound is currently being developed by Roche as RO5313534 [146]. R3487/MEM3454 is an orally active $\alpha 7 \mathrm{nAChR}$ agonist with high affinity for native rat $\alpha 7 \mathrm{nAChRs}(K \mathrm{i}=6 \mathrm{nM})$. R3487/MEM3454 also showed a similar high affinity binding to human recombinant $5-\mathrm{HT}_{3}$ receptors $(K \mathrm{i}=2 \mathrm{nM})$. Functionally, R3487/MEM3454, with a molecular weight of 306.79 , acted as a partial agonist in monkey recombinant $\alpha 7$ nAChRs $\left(E_{50}=0.4 \mathrm{nM}\right)$ and displayed an antagonist action against native guinea pig 5- $\mathrm{HT}_{3}$ receptors. R3487/MEM3454 lacked affinity at $\alpha 4 \beta 2 \mathrm{nAChRs}$ and had no activity at other nicotinic or other CNS receptor subtypes. Additionally, R3487/MEM3454 was demonstrated to be efficacious in several behavioral paradigms representing multiple cognitive domains (episodic, spatial, working, attentional and executive memory functions) in young and aged rodents as well as non-human primates.* Interestingly, R3487/MEM3454 can increase both dopamine and ACh efflux in the rat medial prefrontal cortex and hippocampus when administered subcutaneously. These effects were completely blocked by MLA in both brain regions.

Currently RO5313534 (formerly R3487/MEM 3454) is being developed for treatment of $\mathrm{AD}$ and cognitive impairment in schizophrenia. Three different doses of RO5313534 (as R3487/MEM3454) were evaluated in a phase IIa trial in 80 patients with mild to moderate AD [146]. The 2 lower doses ( 5 and $15 \mathrm{mg} /$ day) were associated with significant improvements compared with placebo on several efficacy measures $(\mathrm{P} \leq 0.05)$. Constipation was the only adverse event that was found to occur substantially more frequently in the R3487/MEM3454 groups compared with the placebo group ( $43 \%$ vs $5 \%$, respectively); no serious adverse events were attributed to the study drug. A second phase II trial was initiated in April 2009 to assess the safety and efficacy of 4 different dosages of RO5313534 as an adjunctive therapy to donepezil 5 or $10 \mathrm{mg} /$ day in patients with mild to moderate AD.

\footnotetext{
*** Wallace, T.L.; Chiu, H.; Dao, D.A.; Lowe, D.A.; Porter, R.; Santarelli, L. R3487/MEM 3454, a novel nicotinic $\alpha 7$ receptor partial agonist, improves attention and working memory performance in cynomolgus macaques. Biochem. Pharmacol., 2009, 78, 912 .
}

\section{Servier}

Researchers at Servier reported 2-[2-(4-bromophenyl)-2oxoethyl]-1-methyl pyridinium, S 24795 (Fig. 15), as a partial agonist for $\alpha 7 \mathrm{nAChRs}$ [147]. S 24795 was selected from a series of bromophenyl pyridinium derivatives. S 24795 showed a moderate affinity to native rat $\alpha 7 \mathrm{nAChR}$ $\left(\mathrm{IC}_{50}=4.6 \mu \mathrm{M}\right)$ but did not show any affinity to $\alpha 4 \beta 2$ $\mathrm{nAChR}$, muscle-type nicotinic receptors or ganglionic-type nicotinic receptors. S 24795 is a partial agonist of $\alpha 7 \mathrm{nAChR}$ with an $\mathrm{EC}_{50}$ of $34 \pm 11 \mu \mathrm{M}$ and approximately $10 \%$ activity relative to ACh. S 24795 enhances long-term potentiation at CA3-CA1 synapses in the adult mouse hippocampus [148]. This effect was considered to be mediated by $\alpha 7 \mathrm{nAChRs,}$ since it was prevented by MLA $(10 \mu \mathrm{M})$ and was absent in $\alpha 7$-knockout mice. S 24795 improved contextual memory in aged mice [149] and aging-related deficits in declarative and working memory in mice [150]. Interestingly, in vitro exposure of $S 24795$ reduced the existing $A \beta_{42}-\alpha 7 \mathrm{nAChR}$ complexes in AD frontal cortex synaptosomes [94]. Furthermore, in vitro exposure of S 24795 normalized $\alpha 7$ nAChR- and NMDA receptor-mediated $\mathrm{Ca}^{2+}$ influx and improved NMDA receptor signaling in $A D$ and $A \beta_{42^{-}}$ exposed control brain synaptosomes. S 24795 facilitates $\mathrm{A} \beta_{42}$ release from $A \beta_{42}-\alpha 7 \mathrm{nAChR}$ and $-\mathrm{A} \beta_{42}$ complexes by interacting with the $A \beta_{15-20}$ region of $A \beta_{42}$, the pivotal $A \beta_{42^{-}}$ binding domain to the $\alpha 7 \mathrm{nAChR}$.

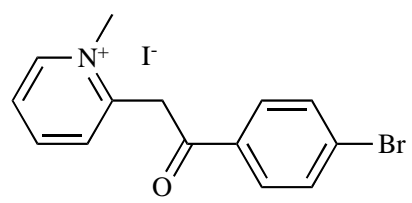

S 24795

Fig. (15). Chemical structure of S 24795.

\section{EnVivo}

Very recently, researchers at EnVivo Pharmaceuticals Inc. reported EVP-6124 as a novel $\alpha 7 \mathrm{nAChR}$ agonist. ${ }^{\dagger \dagger}$ The chemical structure of EVP-6124 was not disclosed. EVP6124 is a selective and potent $\alpha 7 \mathrm{nAChR}$ agonist $(\mathrm{Ki}=4.3$ $\mathrm{nM})$ that has antagonist activity at the $5-\mathrm{HT}_{3}$ receptor $\left(\mathrm{IC}_{50}=\right.$ $299 \mathrm{nM}$ ), and limited or no activity on other receptors. EVP6124 has an excellent brain to plasma ratio and has shown marked efficacy and potency in a number of animal models of cognition. In rats with scopolamine-induced memory deficit, a single dose of EVP-6124 reverses the short-term memory impairment in an object-recognition task. In a model of natural forgetting of the novel objectiverecognition task, EVP-6124 was effective at preventing natural forgetting when given after the first trial. EVP-6124 was also effective in this model when given after the first trial or when given only before the second trial. Furthermore, EVP-6124 also reversed scopolamine-induced deficits in a water maze repeated acquisition task model. These observations suggest that EVP-6124 may enhance

\footnotetext{
${ }^{\dagger \dagger}$ Koenig, G. EVP-6124, a novel $\alpha 7$ nAChR agonist for the treatment of cognitive impairments in Alzheimer's disease \& schizophrenia. Nicotinic acetylcholine receptors as therapeutic targets: emerging frontiers on basic research and clinical science; Chicago, IL, Oct. 14-Oct. 17, 2009.
} 
acquisition as well as consolidation and retrieval processes. Further preclinical investigation of EVP-6124 revealed a large safety margin relative to systemic exposure of EVP6124 based on the lack of an observable adverse effect level in dogs. In phase 1 clinical trials, the safety and tolerability of EVP-6124 has been demonstrated in healthy volunteers as well as in subjects with schizophrenia and AD. The efficacy of EVP-6124 is currently being investigated in AD as well as in cognitive impairment associated with schizophrenia.

\section{Tropisetron}

Both $\alpha 7 \mathrm{nAChRs}$ and $5-\mathrm{HT}_{3}$ receptors are members of the superfamily of ligand-gated ion channels [23, 28]. These two receptors share the greatest similarity within the family, displaying approximately $30 \%$ sequence homology [151]. Tropisetron and ondansetron (Fig. 16) are potent $5-\mathrm{HT}_{3}$ receptor antagonists that are widely used in the treatment of patients with chemotherapy-induced or postoperative nausea and vomiting [23]. It has been reported that tropisetron is a partial agonist of $\alpha 7 \mathrm{nAChRs}$ with a high affinity, whereas ondansetron has a weak affinity at $\alpha 7$ nAChRs [152, 153]. We found that tropisetron improves the deficient inhibitory processing of $\mathrm{P} 20-\mathrm{N} 40$ in $\mathrm{DBA} / 2$ mice, and that improvement by tropisetron could be antagonized by coadministration of MLA [154]. Furthermore, we reported that PCP-induced cognitive deficits could be improved by subsequent subchronic administration of tropisetron, but not ondansetron, and that improvement by tropisetron could be antagonized by co-administration of MLA [155]. These findings suggest that tropisetron could improve abnormal auditory gating of $\mathrm{P} 20-\mathrm{N} 40$ and $\mathrm{PCP}$-induced cognitive deficits in mice via $\alpha 7 \mathrm{nAChRs}$. In addition, we reported that tropisetron $(10 \mathrm{mg})$ could improve deficits of P50 suppression in schizophrenic patients [156]. A randomized, placebo-controlled study of tropisetron on cognitive dysfunction in schizophrenic patients is currently underway at Chiba University.

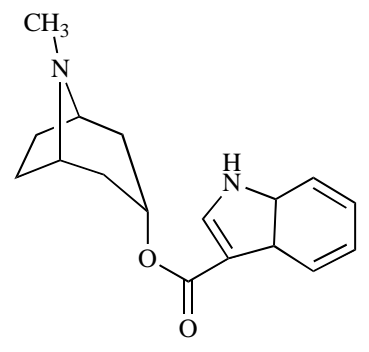

Tropisetron

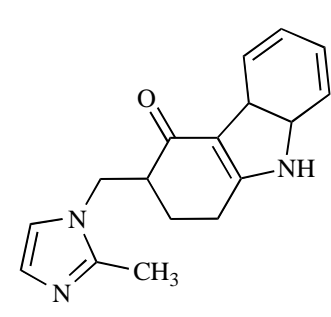

Ondansetron
Fig. (16). Chemical structure of tropisetron and ondansetron.

\section{CONCLUDING REMARKS}

As described above, accumulating evidence suggests that $\alpha 7 \mathrm{nAChRs}$ play an important role in the pathophysiology of neuropsychiatric diseases, including schizophrenia and AD. Hence, a number of pharmaceutical industries have developed selective and high affinity $\alpha 7 \mathrm{nAChR}$ agonists as therapeutic drugs for these neuropsychiatric diseases. Over the past decade, a variety of largely quinuclidine pharmacophore-based agonists of $\alpha 7$ nAChRs have emerged, including AR-R17779, PNU-282987, PHA543613, PHA-568487, W-56203, ABBF and JN403. In the past 10 years, several $\alpha 7 \mathrm{nAChR}$ agonists (DMXB-A, PHA543613, PHA-568487, R3487/MEM 3545 and tropisetron) have entered clinical trials for potential use in schizophrenia or AD. Today, lead optimization efforts and structureactivity relationship studies have identified several different pharmacophore-based compounds, including biarylamine derivatives (TC-1698, TC-5619, PHA-709829, SSR180711, A-844606 and A-582941) and others. Some of these new compounds have entered preclinical validation studies as candidates for clinical trial.

In vivo positron emission tomography (PET) imaging of $\alpha 7 \mathrm{nAChRs}$ in the intact human brain provides a method for quantitative study of $\alpha 7 \mathrm{nAChR}$-related pathophysiology in neuropsychiatric diseases [157]. Very recently, we developed the novel PET ligand, $\left[{ }^{11} \mathrm{C}\right] \mathrm{CHIBA}-1001$ (Fig. 17), for $\alpha 7 \mathrm{nAChRs}$ in the human brain [158, 159]. To the best of our knowledge, there are no other PET ligands for $\alpha 7$ $\mathrm{nAChRs}$ available for human use. The in vivo determination of $\alpha 7$ nAChR receptor occupancy using PET and $\left[{ }^{11} \mathrm{C}\right]$ CHIBA-1001 allows for demonstration of the target engagement and assessment of the titration for potential dose regimens in humans. In addition, a clinical PET study in patients with schizophrenia or AD using $\left[{ }^{11} \mathrm{C}\right] \mathrm{CHIBA}-1001$ is currently underway.<smiles>Cc1ccc(OC(=O)N2CCN3CCC2C3)cc1</smiles>

Fig. (17). Chemical structure of $\left[{ }^{11} \mathrm{C}\right] \mathrm{CHIBA}-1001$.

\section{ACKNOWLEDGEMENTS}

This study was supported by a grant from the Program for Promotion of Fundamental Studies in Health Sciences of the National Institute of Biomedical Innovation of Japan (to K.H., ID\#:06-46).

\section{ABBREVIATIONS}

$\mathrm{ACh}$

$\mathrm{AD}$

ADHD

nAChR

$5-\mathrm{HT}_{3}$

CNS

CSF

NMDA

CHRNA7

NB

$\mathrm{A} \beta$

$\mathrm{EC}_{50}$

i.v.
$=$ Acetylcholine

$=$ Alzheimer's disease

$=$ Attention deficit hyperactivity disorder

$=$ Nicotinic acetylcholine receptor

= 5-hydroxytriptamine- 3

$=$ Central nervous system

$=$ Cerebrospinal fluid

$=\mathrm{N}$-methyl-D-aspartate

$=\alpha 7 \mathrm{nAChR}$ subunit gene

$=$ Nucleus basalis

$=\beta$-Amyloid

$=$ Half maximum $(50 \%)$ effective concentration

$=$ Intravenous 


$$
\begin{aligned}
& \text { i.p. } \quad=\text { Intraperitoneal } \\
& \text { p.o. }=\text { Peroral } \\
& \text { s.c. }=\text { Subcutaneous } \\
& \text { PPI } \quad=\text { Pre-pulse inhibition } \\
& \text { Pgp = P-glycoprotein } \\
& \text { hERG }=\text { Human ether-a-go-go } \\
& \text { JAK2 }=\text { JANUS kinase } 2 \\
& \text { PI3K = Phosphoinositide 3-kinase } \\
& \text { Arc = Activity-regulated cytoskeleton-associated } \\
& \text { protein } \\
& \text { ERK1/2 = Extracellular signal-regulated protein } 1 / 2 \\
& \text { CREB }=\mathrm{cAMP} \text { response element-binding protein } \\
& \text { GSK3 } \beta=\text { Glycogen synthase kinase } 3 \beta \\
& \text { DMXB-A = 3-(2,4)-dimethoxybenzilidine anabaseine } \\
& \text { (GTS-21) } \\
& \text { DMAB = 3-(4)-dimethylaminobenzylidine anabaseine } \\
& \text { DMAC = 3-(4)-dimethylaminocinnamylidine } \\
& \text { 4-OH- = 3-(4-hydroxy-2-methoxybenzylidine) ana- } \\
& \text { DMXB-A baseine } \\
& \text { AR-R17779 = (-)-spiro[1-azabicyclo[2.2.2] octane-3, } 5^{\prime} \text { - } \\
& \text { oxazolidin- } 2 \text { '-one] } \\
& \text { SIB1765F = [ }] \text {-5-ethynyl-3-(1-methyl-2-pyrrolidinyl)- } \\
& \text { pyridine fumarate }
\end{aligned}
$$$$
\text { AZD0328 = }\left(2^{\prime} R\right) \text {-spiro-[1-azabicyclo[2.2.2] octane-3, } 2^{\prime}-
$$$$
\left(3^{\prime} H\right) \text {-furo[2,3-b]pyridine D-tartrate }
$$

$\mathrm{W}-56203=(R)-3^{\prime}-(3-$ methylbenzo $[b]$ thiophen-5-yl $) \mathrm{s}-$ piro[1-azabicyclo[2.2.2] octane-3,5'-oxazolidin]-2'-one

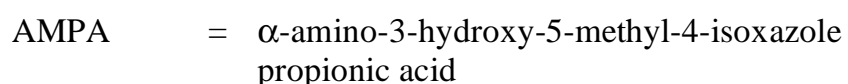

$$
\text { MLA = Methyllycaconitine }
$$$$
\text { Dizocilpine }=(+)-5 \text {-methyl-10,11-dihydro-5H-dibenzo- }
$$$$
\text { (MK-801) [a,d]cyclohepten-5,10-imine maleate }
$$$$
\text { TC-1698 = 2-(3-pyridyl)-1-azabicyclo[3.2.2]nonane }
$$$$
\text { TC-5619 = N-\{(2R,3R)-2-[(pyridine-3-yl }) \text { methyl }] \text { quin- }
$$$$
\text { uclidin-3-yl\} benzofuran-2-carboxamide }
$$

PNU-282987 = N-[(3R)-1-azabicyclo[2.2.2]oct-3-yl]-4-chlorobenzamide hydrochloride

PHA-543613 $=N-[(3 R)-1$-azabicyclo[2.2.2] oct-3-yl]furo[2,3-c]pyridine-5-carboxamide

PHA-568487 = 2,3-dihydro- $N$ - $[(R)$-quinuclidine-3-yl $]$ benzo[b][1,4]dioxine-6-carboxamide

PHA-709829 $=N-[(3 R, 5 R)-1$-aza-bicyclo[3.2.1]octan-3-yl $]$ furo[2,3-c]pyridine-5-carboxamid

SSR180711 = 4-bromophenyl 1,4-diazabicyclo[3.2.2]nonane-4-carboxylate hydrochloride

PCP $=$ Phencyclidine

\section{REFERENCES}

[1] Paterson, D.; Nordberg, A. Neuronal nicotinic receptors in the human brain. Prog. Neurobiol., 2000, 61, 75-111.

[2] Dani, J.A.; Ji, D.; Zhou, F.M. Selective dopamine filter of glutamate striatal afferents. Neuron, 2001, 31, 349-352.

[3] Hogg, R.C.; Raggenbass, M.; Bertrand, D. Nicotinic acetylcholine receptors: from structure to brain function. Rev. Physiol. Biochem. Pharmacol., 2003, 147, 1-46.

[4] Dajas-Bailador, F.; Wonnacott, S. Nicotinic acetylcholine receptors and the regulation of neuronal signalling. Trends Pharmacol. Sci., 2004, 25, 317-324.

[5] Buisson, B.; Bertrand, D. Nicotine addiction: the possible role of functional upregulation. Trends Pharmacol. Sci., 2002, 23, 130136.

[6] Nomikos, G.G.; Schilström, B.; Hildebrand, B.E.; Panagis, G.; Grenhoff, J.; Svensson, T.H. Role of $\alpha 7$ nicotinic receptors in nicotine dependence and implications for psychiatric illness. Behav. Brain Res., 2000, 113, 97-103.

[7] Mathieu-Kia, A.M.; Kellogg, S.H.; Butelman, E.R.; Kreek, M.J. Nicotine addiction: insights from recent animal studies. Psychopharmacology (Berl.), 2002, 162, 102-118.

[8] Picciotto, M.R.; Caldarone, B.J.; King, S.L.; Zachariou, V. Nicotinic receptors in the brain. Links between molecular biology and behavior. Neuropsychopharmacology, 2000, 22, 451-465.

[9] Picciotto, M.R.; Corrigall, W.A. Neuronal systems underlying behaviors related to nicotine addiction: neural circuits and molecular genetics. J. Neurosci., 2002, 22, 3338-3341.

[10] Martin, L.F.; Kem, W.R.; Freedman, R. $\alpha 7$ nicotinic receptor agonists: potential new candidates for the treatment of schizophrenia. Psychopharmacology (Berl.), 2004, 174, 54-64.

[11] Newhouse, P.A.; Potter, A.; Singh, A. Effects of nicotinic stimulation on cognitive performance. Curr. Opin. Pharmacol., 2004, 4, 36-46.

[12] Benowitx, N.L. Pharmacology of nicotine: addiction and therapeutics. Ann. Rev. Pharmacol. Toxicol., 1996, 36, 597-613. 
[13] Holladay, M.W.; Dart, M.J.; Lynch, J.K. Neuronal nicotinic acetylcholine receptors as targets for drug discovery. J. Med. Chem., 1997, 40, 4169-4194.

[14] Léna, C.; Changeux, J.P. Pathological mutations of nicotinic receptors and nicotine-based therapies for brain disorders. Curr. Opin. Neurobiol., 1997, 7, 674-682.

[15] Buccafusco, J.J.; Terry, A.V. Multiple central nervous system targets for eliciting beneficial effects on memory and cognition. $J$. Pharmacol. Exp. Ther., 2000, 295, 438-446.

[16] Gotti, C.; Fornasari, D.; Clementi, F. Human neuronal nicotinic receptors. Prog. Neurobiol., 1997, 53, 199-237.

[17] Gotti, C.; Carbonnelle, E.; Moretti, M.; Zwart, R.; Clementi, F. Drugs selective for nicotinic receptor subtypes: a real possibility or a dream? Behav. Brain Res., 2000, 113, 183-192.

[18] Lloyd, G.K.; Williams, M. Neuronal nicotinic acetylcholine receptors as novel drug targets. J. Pharmacol. Exp. Ther., 2000, 292, 461-467.

[19] Dwoskin, L.P.; Crooks, P.A. Competitive neuronal nicotinic receptor antagonists: a new direction for drug discovery. $J$. Pharmacol. Exp. Ther., 2001, 298, 395-402.

[20] Schmitt, J.D. Exploring the nature of molecular recognition in nicotinic acetylcholine receptors. Curr. Med. Chem., 2000, 7, 749800.

[21] Levin, E.D. Nicotinic receptor subtypes and cognitive function. $J$. Neurobiol., 2002, 53, 633-640.

[22] Hogg, R.C.; Bertrand, D. Nicotinic acetylcholine receptors as drug targets. Curr. Drug Targets CNS Neurol. Disord., 2004, 3, 123130.

[23] Hashimoto, K.; Koike, K.; Shimizu, E.; Iyo, M. $\alpha 7$ Nicotinic receptor agonists as potential therapeutic drugs for schizophrenia. Curr. Med. Chem. CNS Agents, 2005, 5, 171-184.

[24] Flores, C.M.; Rogers, S.W.; Pabreza, L.A.; Wolfe, B.B.; Kellar, K.J. A subtype of nicotinic cholinergic receptor in rat brain is composed of $\alpha 4$ and $\beta 2$ subunits and is up-regulated by chronic nicotine treatment. Mol. Pharmacol., 1992, 41, 31-37.

[25] Marks, M.J.; Collins, A.C. Characterization of nicotine binding in mouse brain and comparison with the binding of $\alpha$-bungarotoxin and quinuclidinyl benzilate. Mol. Pharmacol., 1982, 22, 554-564.

[26] Broide, R.S.; Leslie, F.M. The $\alpha 7$ nicotinic acetylcholine receptor in neuronal plasticity. Mol. Neurobiol., 1999, 20, 1-16.

[27] Jones, S.; Sudweeks, S.; Yakel, J.L. Nicotinic receptors in the brain: correlating physiology with function. Trends Neurosci., 1999, 22, 555-561.

[28] Cordero-Erausquin, M.; Marubio, L.M.; Klink, R.; Changeux, J.P. Nicotinic receptor function: new perspectives from knockout mice. Trends Pharamacol. Sci., 2000, 21, 211-217.

[29] Picciotto, M.R.; Caldarone, B.J.; Brunzall, D.H.; Zachariou, V.; Stevens, T.R.; King, S.L. Neuronal nicotinic acetylcholine receptor subunit knockout mice: physiological and behavioral phenotypes and possible clinical implications. Pharmacol. Ther., 2001, 92, 89108.

[30] Champtiaux, N.; Changeux, J.P. Knockout and knockin mice to investigate the role of nicotinic receptors in the central nervous system. Prog. Brain Res., 2004, 145, 235-251.

[31] Papke, R.L.; Bencherif, M.; Lippiello, P. An evaluation of neuronal nicotinic acetylcholine receptor activation by quaternary nitrogen compounds indicates that choline is selective for the $\alpha 7$ subtype. Neurosci. Lett., 1996, 213, 201-204.

[32] Alkondon, M.; Pereira, E.F.R.; Cortes, W.S.; Maelicke, A.; Albuquerque, E.X. Choline is a selective agonist of $\alpha 7$ nicotinic acetylcholine receptors in the rat brain neurons. Eur. J. Neurosci., 1997, 9, 2734-2742.

[33] Alkondon, M.; Pereira, E.F.R.; Braga, M.F.M.; Albuquerque, E.X. Contribution of nicotinic receptors to the function of synapses in the central nervous system: the action of choline as a selective agonist of $\alpha 7$ receptors. J. Physiol.(Paris), 1998, 92, 309-316.

[34] Uteshev, V.V.; Meyer, E.M.; Papke, R.L. Regulation of neuronal function by choline and 4OH-GTS-21 through $\alpha 7$ nicotinic receptors. J. Neurophysiol., 2003, 89, 1797-1806.

[35] Berg, D.K.; Conroy, W.G. Nicotinic $\alpha 7$ receptors: synaptic options and downstream signaling in neurons. J. Neurobiol., 2002, 53, 512523.

[36] Gray, R.; Rajan, A.S.; Radcliffe, K.A.; Yakehiro, M.; Dani, J.A. Hippocampal synaptic transmission enhanced by low concentrations of nicotine. Nature, 1996, 383, 713-716.
[37] Hashimoto, K.; Shimizu, E.; Iyo, M. Dysfunction of glia-neuron communication in pathophysiology of schizophrenia. Curr. Psychiatry Rev., 2005, 1, 151-163.

[38] Hashimoto, K.; Hattori, E. Part II. Candidate Gene and Models. 4. Neurotransmission. In: Neurogenetics of Psychiatric Disorders. Sawa, A., McInnis, M.G., Eds.; Informa Healthcare: New York, 2007, pp. 81-100.

[39] Hashimoto, K.; Iyo, M. Amyloid cascade hypothesis of Alzheimer's disease and $\alpha 7$ nicotinic receptor. Nihon Shinkei Seishin Yakurigaku Zasshi 2002, 22, 3-13.

[40] Bourin, M.; Ripoll, N.; Dailly, E. Nicotinic receptors and Alzheimer's disease. Curr. Med. Res. Opin., 2003, 19, 169-177.

[41] D'Andrea, M.R.; Nagele, R.G. Targeting the $\alpha 7$ nicotinic acetylcholine receptor to reduce amyloid accumulation in Alzheimer's disease pyramidal neurons. Curr. Pharm. Des., 2006, 12, 677-684.

[42] Härfstrand, A.; Adem, A.; Fuxe, K.; Agnati, L.; Andersson, K.; Nordberg, A. Distribution of nicotinic cholinergic receptors in the rat tel- and diencephalon: a quantitative receptor autoradiographical study using $\left[{ }^{3} \mathrm{H}\right]$-acetylcholine, $\left[\alpha_{-}{ }^{125} \mathrm{I}\right]$ bungarotoxin and $\left[{ }^{3} \mathrm{H}\right]$ nicotine. Acta Physiol. Scand., 1988, 132, 1-14.

[43] Freedman, R.; Wetmore, C.; Strömberg, I.; Leonard, S.; Olson, L. $\alpha$-Bungarotoxin binding to hippocampal interneurons: immunocytochemical characterization and effects on growth factor expression. J. Neurosci., 1993, 13, 1965-1975.

[44] Freedman, R.; Adler, L.E.; Bickford, P.; Byerley, W.; Coon, H.; Cullum, C.M.; Griffith, J.; Harris, J.G.; Leonard, S.; Miller, C.; Myles-Worsey, M.; Nagamoto, H.T.; Rose, G.; Waldo, M. Schizophrenia and nicotinic receptors. Harv. Rev. Psychiatry, 1994, 2, 179-192.

[45] Freedman, R.; Hall, M.; Adler, L.E.; Leonard, S. Evidence in postmortem brain tissue for decreased numbers of hippocampal nicotinic receptors in schizophrenia. Biol. Psychiatry, 1995, 38, 2233.

[46] Court, J.; Spurden, D.; Lloyd, S.; McKeith, I.; Ballard, C.; Cairns, N.; Kerwin, R.; Perry, R.; Perry, E. Neuronal nicotinic receptors in dementia with Lewy bodies and schizophrenia: $\alpha$-bungarotoxin and nicotine binding in the thalamus. J. Neurochem., 1999, 73, 15901597.

[47] Guan, Z.Z.; Zhang, X.; Blennow, K.; Nordberg, A. Decreased protein level of nicotinic receptor $\alpha 7$ subunit in the frontal cortex from schizophrenic brain. Neuroreport, 1999, 10, 1779-1782.

[48] Marutle, A.; Zhang, X.; Court, J.; Piggott, M.; Johnson, M.; Perry, R.; Perry, E.; Nordberg, A. Laminar distribution of nicotinic receptor subtypes in cortical regions in schizophrenia. J. Chem. Neuroanat., 2001, 22, 115-126.

[49] Leonard, S.; Adams, C.; Breese, C.R.; Adler, L.E.; Bickford, P.; Byerley, W.; Coon, H.; Griffith, J.M.; Miller, C.; Myles-Worsley, M.; Nagamoto, H.T.; Rollins, Y.; Stevens, K.E.; Waldo, M.; Freedman, R. Nicotinic receptor function in schizophrenia. Schizophr. Bull., 1996, 22, 431-445.

[50] Freedman, R.; Adams, C.E.; Leonard, S. The $\alpha 7$-nicotinic acetylcholine receptor and the pathology of hippocampal interneurons in schizophrenia. J. Chem. Neuroanat., 2000, 20, 299306.

[51] Perl, O.; Ilani, T.; Strous, R.D.; Lapidus, R.; Fuchs, S. The $\alpha 7$ nicotinic acetylcholine receptor in schizophrenia: decreased mRNA levels in peripheral blood lymphocytes. FASEB J., 2003, 17, 19481950.

[52] Braff, D.L.; Geyer, M.A. Sensorimotor gating and schizophrenia. Human and animal model studies. Arch. Gen. Psychiatry, 1990, 47, 181-188.

[53] Adler, L.E.; Olincy, A.; Waldo, M.; Harris, J.G.; Giffith, J.; Stevens, K.; Flach, K.; Nagamoto, H.; Bickford, P.; Leonard, S.; Freedman, R. Schizophrenia, sensory gating, and nicotinic receptors. Schizophr. Bull., 1998, 24, 189-202.

[54] Braff, D.; Freedman, R. Neuropsychopharmacology, In: The Fifth Generation of Progress; Davis. K.L., Charney, D., Coyle, J.T., Nemeroff, C.N., Eds.; Lippincott Williams \& Wilkins: Philadelphia, PA, 2003; pp. 703-716.

[55] Freedman, R.; Adler, L.E.; Gerhardt, G.A.; Waldo, M.; Baker, N.; Rose, G.M.; Drebing, C.; Nagamoto, H.; Bickford-Wimer, P.; Franks, R. Neurobiological studies of sensory gating in schizophrenia. Schizophr. Bull., 1987, 13, 669-678. 
[56] Adler, L.E.; Hoffer, L.J.; Griffith, J.; Waldo, M.C.; Freedman, R. Normalization by nicotine of deficient auditory sensory gating in the relatives of schizophrenics. Biol. Psychiatry, 1992, 32, 607-616.

[57] Adler, L.E.; Hoffer, L.J.; Wiser, A.; Freedman, R. Normalization of auditory physiology by cigarette smoking in schizophrenic patients. Am. J. Psychiatry, 1993, 150, 1856-1861.

[58] Freedman, R.; Coon, H.; Myles-Worsley, M.; Orr-Urtreger, A.; Olincy, A.; Davis, A.; Polymeropoulos, M.; Holik, J.; Hopkins, J.; Hoff, M.; Rosenthal, J.; Waldo, M.C.; Reimherr, F.; Wender, P.; Yaw, J.; Young, D.A.; Breese, C.R.; Adams, C.; Patterson, D.; Adler, L.E.; Kruglyak, L.; Leonard, S.; Byerley, W. Linkage of a neurophysiological deficit in schizophrenia to a chromosome 15 locus. Proc. Natl. Acad. Sci. USA, 1997, 94, 587-592.

[59] Kaufmann, C.A.; Suarez, B.; Malaspina, D.; Pepple, J.; Svrakic, D.; Markel, P.D.; Meyer, J.; Zambuto, C.T.; Schmitt, K.; Matise, T.C.; Harkavy Friedman, J.M.; Hampe, C.; Lee, H.; Shore, D.; Wynne, D.; Faraone, S.V.; Tsuang, M.T.; Cloninger, C.R. NIMH genetics initiative millenium schizophrenia consortium: linkage analysis of African-American pedigrees. Am. J. Med. Genet., 1998, 81, 282289.

[60] Leonard, S.; Gault, J.; Moore, T.; Hopkins, J.; Robinson, M.; Olincy, A.; Adler, L.E.; Cloninger, C.R.; Kaufmann, C.A.; Tsuang, M.T.; Faraone, S.V.; Malaspina, D.; Svrakic, D.M.; Freedman, R. Further investigation of a chromosome 15 locus in schizophrenia: analysis of affected sibpairs from the NIMH genetics initiative. Am. J. Med. Genet., 1998, 81, 308-312.

[61] Gault, J.; Robinson, M.; Berger, R.; Drebing, C.; Logel, J.; Hopkins, J.; Moore, T.; Jacobs, S.; Meriwether, J.; Choi, M.J.; Kim, E.J.; Walton, K.; Buiting, K.; Davis, A.; Breese, C.; Freedman, R.; Leonard, S. Genomic organization and partial duplication of the human $\alpha 7$ neuronal nicotinic acetylcholine receptor gene (CHRNA7). Genomics, 1998, 52, 173-185.

[62] Leonard, S.; Gault, J.; Hopkins, J.; Logel, J.; Vianzon, R.; Short, M.; Drebing, C.; Berger, R.; Venn, D.; Sirota, P.; Zerbe, G.; Olincy, A.; Ross, R.G.; Adler, L.E.; Freedman, R. Association of promoter variants in the $\alpha 7$ nicotinic acetylcholine receptor subunit gene with an inhibitory deficit found in schizophrenia. Arch. Gen. Psychiatry, 2002, 59, 1085-1096.

[63] De Luca, V.; Wong, A.H.C.; Muller, D.J.; Wong, G.W.H.; Tyndale, R.F.; Kennedy, J.L. Evidence of association between smoking and $\alpha 7$ nicotinic receptor subunit gene in schizophrenia patients. Neuropsychopharmacology, 2004, 29, 1522-1526.

[64] Simosky, J.K.; Stevens, K.E.; Freedman, R. Nicotinic agonists and psychosis. Curr. Drug Targets CNS Neurol. Disord., 2002, 1, 433442 .

[65] Leonard, S. Consequences of low levels of nicotinic acetylcholine receptors in schizophrenia for drug development. Drug Dev. Res., 2003, 60, 127-136.

[66] Freedman, R.; Leonard, S.; Waldo, M.; Gault, J.; Olincy, A.; Adler, L.E. Characterization of allelic variants at chromosome $15 \mathrm{q} 14$ in schizophrenia. Genes Brain Behav., 2006, 5 (Suppl 1), 14-22.

[67] Zammit, S.; Spurlock, G.; Williams, H.; Norton, N.; Williams, N.; O'Donovan, M.C.; Owen, M.J. Genotype effects of CHRNA7, CNR1 and COMT in schizophrenia: interactions with tobacco and cannabis use. Br. J. Psychiatry, 2007, 191, 402-407.

[68] Dempster, E.L.; Toulopoulou, T.; McDonald, C.; Bramon, E.; Walshe, M.; Wickham, H.; Sham, P.C.; Murray, R.M.; Collier, D.A. Episodic memory performance predicted by the $2 \mathrm{bp}$ deletion in exon 6 of the "alpha 7-like" nicotinic receptor subunit gene. Am. J. Psychiatry, 2006, 163, 1832-1034.

[69] Olincy, A.; Stevens, K.E. Treating schizophrenia symptoms with an $\alpha 7$ nicotinic agonist, from mice to men. Biochem. Pharmacol., 2007, 74, 1192-1201.

[70] Adams, C.E.; Stevens, K.E. Evidence for a role of nicotinic acetylcholine receptor in schizophrenia. Front. Biosci., 2007, 12, 4755-4772.

[71] Bowen, D.M. Biomedical assessment of neurotransmitter and metabolic dysfunction and cerebral atrophy in Alzheimer's disease. In: Biological Aspects of Alzheimer's Disease; Katzman, R., Ed.; Cold Spring Harbor Laboratory: Cold Spring Harbor, NY, 1983; pp. 219-232.

[72] Cummings, J.L.; Benson, D.F. The role of the nucleus basalis of Meynert and dementia: Review and reconsideration. Alzheimer Dis. Assoc. Disord., 1987, 1, 128-145.

[73] Perry, E.K.; Court, J.A.; Piggott, M.A.; Perry, R.H. Cholinergic component of dementia and aging. In: Dementia and Normal
Aging; Huppert, F.A.; Brayne, C.; O’Connor, D.W. Eds.; Cambridge University Press: New York, 1994; pp. 437-469.

[74] Davies, P.; Feisullin, S. Postmortem stability of $\alpha$-bungarotoxin binding sites in mouse and human brain. Brain Res., 1981, 216, 449-454.

[75] Sugaya, K.; Giacobini, E.; Chiappinelli, V.A. Nicotinic acetylcholine receptor subtypes in human frontal cortex: changes in Alzheimer's disease. J. Neurosci. Res., 1990, 27, 349-359.

[76] Hellström-Lindhal, E.; Mousavi, M.; Zhang, X.; Ravid, R.; Nordberg, A. Regional distribution of nicotinic receptor subunit mRNAs in human brain: Comparison between Alzheimer and normal brain. Brain Res. Mol. Brain Res., 1999, 66, 94-103.

[77] Guan, Z.-Z.; Zhang, X.; Ravid, R.; Nordberg, A. Decreased protein levels of nicotinic receptor subunits in the hippocampus and temporal cortex of patients with Alzheimer's disease. $J$. Neurochem., 2000, 74, 237-243.

[78] Martin-Ruiz, C.M.; Court, J.A.; Molnar, E.; Lee, M.; Gott, C.; Mamalki, A.; Tsouloufis, T.; Tzartos, S.; Ballard, C.; Perry, R.H.; Perry, E.K. $\alpha 4$ but not $\alpha 3$ and $\alpha 7$ nicotinic acetylcholine receptor subunits are lost from the temporal cortex in Alzheimer's disease. J. Neurochem., 1999, 73, 1635-1640.

[79] Burghaus, L.; Schütz, U.; Krempel, U.; de Vos, R.A.; Jansen Steur, E.N.; Wevers, A.; Lindstrom, J.; Schröder, H. Quantitative assessment of nicotinic acetylcholine receptor proteins in the cerebral cortex of Alzheimar's patients. Brain Res. Mol. Brain Rev., 2000, 76, 385-388.

[80] Wevers, A.; Monteggia, L.; Nowacki, S.; Bloch, W.; Schütz, U.; Lindstrom, J.; Pereira, E.F.; Eisenberg, H.; Giacobini, E.; de Vos, R.A.; Steur, E.N.; Maelicke, A.; Albuquerque. E.X.; Schröder, H. Expression of nicotinic acetylcholine receptor subunits in the cerebral cortex in Alzheimer's disease-histotopographical correlation with amyloid plaques and hyperphosphorylated tauprotein. Eur. J. Neurosci., 1999, 11, 2551-2565.

[81] Court, J.; Martin-Ruiz, C.; Piggott, M.; Spurden, D.; Griffiths, M.; Perry, E. Nicotinic receptor abnormalities in Alzheimer's disease. Biol. Psychiatry, 2001, 49, 175-184.

[82] Counts, S.E.; He, B.; Che, S.; Iknomovic, M.D.; DeKosky, S.T.; Ginsberg, S.D.; Mufson, E.J. $\alpha 7$ Nicotinic receptor up-regulation in cholinergic basal forebrain neurons in Alzheimer disease. Arch. Neurol., 2007, 64, 1771-1776.

[83] Ikonomovic, M.D.; Wecker, L.; Abrahamson, E.E.; Wuu, J.; Counts, S.E.; Ginsberg, S.D.; Mufson, E.J.; Dekosky, S.T. Cortical $\alpha 7$ nicotinic acetylcholine receptor and $\beta$-amyloid levels in early Alzheimer's disease. Arch. Neurol., 2009, 66, 646-651.

[84] Carson, R.; Craig, D.; Hart, D.; Todd, S.; McGuinness, B.; Johnston, J.A.; O'Neill, F.A.; Ritchie, C.W.; Passmore, A.P. Genetic variation in the $\alpha 7$ nicotinic acetylcholine receptor is associated with delusional symptoms in Alzheimer's disease. Neuromol. Med., 2008, 10, 377-384.

[85] Jessen, F.; Kucharski, C.; Fries, T.; Papassotiropoulos, A.; Hoenig, K.; Maier, W.; Heun, R. Sensory gating deficit expressed by a disturbed suppression of the P50 event-related potential in patients with Alzheimer's disease. Am. J. Psychiatry, 2001, 158, 13191321.

[86] Wang, H.Y.; Lee, D.H.; D’Andrea, M.R.; Peterson, P.A.; Shank, R.P.; Reitz, A.B. $\beta$-Amyloid Am-42 $_{1}$ binds to $\alpha 7$ nicotinic acetylcholine receptor with high affinity: implications for Alzheimer's disease pathology. J. Biol. Chem., 2000, 275, 5626-5632.

[87] Wang, H.Y.; Lee, D.H.; Davis, C.B.; Shank, R.P. Amyloid petide $\mathrm{A} \beta_{1-42}$ binds selectively and with pico-molar affinity to $\alpha 7$ nicotinic acetylcholine receptors. J. Neurochem., 2000, 75, 1155-1161.

[88] Nagele, R.G.; D’Andrea, M.R.; Anderson, W.J.; Wang, H.-Y. Intracellular accumulation of $\beta$-amyloid - $_{1-42}$ in neurons is facilitated by the $\alpha 7$ nicotinic acetylcholine receptor in Alzheimer's disease. Neuroscience, 2002, 110, $199-211$.

[89] Wang, H.Y.; Li, W.; Benedetti, N.J.; Lee, D.H. $\alpha 7$ Nicotinic acetylcholine receptors mediate $\beta$-amyloid peptides induced tau protein pshophorylation. J. Biol. Chem., 2003, 278, 31547-31553.

[90] Liu, Q.S.; Kawai, H.; Berg, D.K. $\beta$-Amyloid peptide blocks the response of $\alpha 7$-containing nicotinic receptors on hippocampal neurons. Proc. Natl. Acad. Sci., USA, 2001, 48, 4734-4739.

[91] Pettit, D.L.; Shao, Z.; Yakel, J.L. $\beta$-Amyloid ${ }_{1-42}$ peptide directly modulates nicotinic receptors in the rat hippocampal slice. $J$. Neurosci., 2001, 21(RC120), 1-5. 
[92] Lee, D.H.; Wang, H.Y. Differential physiologic responses of $\alpha 7$ nicotinic acetylcholine receptors to $\beta$-amyloid ${ }_{1-40}$ and $\beta$-amyloid ${ }_{1-42}$. J. Neurobiol., 2003, 55, 25-30.

[93] Dziewczapolski, G.; Glogowski, C.M.; Masliah, E.; Heinemann, S.F. Deletion of the $\alpha 7$ nicotinic acetylcholine receptor gene improves cognitive deficits and synaptic pathology in a mouse model of Alzheimer's disease. J. Neurosci., 2009, 29, 8805- 8815.

[94] Wang, H.Y.; Stucky, A.; Liu, J.; Shen, C.; Trocme-Thibierge, C.; Morain, P. Dissociating $\beta$-amyloid from $\alpha 7$ nicotinic acetylcholine receptor by a novel therapeutic agent, S 24795, normalizes $\alpha 7$ nicotinic acetylcholine and NMDA receptor function in Alzheimer's disease brain. J. Neurosci., 2009, 29, 10961-10973.

[95] Kem, W.R. Alzheimer's drug design based upon an invertebrate toxin (anabaseine) which is a potent nicotinic receptor agonist. Invert. Neurosci., 1997, 3, 251-259.

[96] De Fiebre, C.M.; Meyer, E.D.; Henry, J.C.; Muraskin, S.I.; Kem, W.R.; Papke, R.L. Characterization of a series of anabaseinederived compounds reveals that the 3-(4)dimethylaminocinnamylidine derivative is a selective agonist at neuronal nicotinic $\alpha 77^{125} \mathrm{I}-\alpha$-bungarotoxin receptor subtypes. Mol. Pharmacol., 1995, 47, 164-171.

[97] Briggs, C.A.; Anderson, D.J.; Brioni, J.D.; Buccafusco, J.J.; Buckley, M.J.; Campbell, J.E.; Decker, M.W.; Donnelly-Roberts, D.; Elliott, R.L.; Gopalakrishnan, M.; Holladay, M.W.; Hui, Y.H.; Jackson, W.J.; Kim, D.J.; Marsh, K.C.; O'Neill, A.; Prendergast, M.A.; Ryther, K.B.; Sullivan, J.P.; Arneric, S.P. Functional characterization of the novel neuronal nicotinic acetylcholine receptor ligand GTS-21 in vitro and in vivo. Pharmacol. Biochem. Behav., 1997, 57, 231-241.

[98] Meyer, E.M.; Kuryatov, A.; Gerzanich, V.; Lindstrom, J.; Papke, R.L. Analysis of 3-(4-hydroxy, 2-Methoxybenzylidene)anabaseine selectivity and activity at human and rat $\alpha 7$ nicotinic receptors. $J$. Pharmacol. Exp. Ther., 1998, 287, 918-925.

[99] Kem, W.R.; Mahnir, V.; Prokai, L.; Papke, R.L.; Cao, X.; LeFrancois, S.; Wildeboer, K.; Prokai-Tatrai, K.; Porter-Papke, J.; Soti, F. Hydroxy metabolites of the Alzheimer's drug candidate 3[(2,4-dimethoxy)benzylidene]-anabaseine dihydrochloride (GTS21): their molecular properties, interactions with brain nicotinic receptors, and brain penetration. Mol. Pharmacol., 2004, 65, 56-67.

[100] Kem, W.R. The brain $\alpha 7$ nicotinic receptor may be an important therapeutic target for the treatment of Alzheimer's disease: studies with DMXBA (GTS-21). Behav. Brain Res., 2000, 113, 169-181.

[101] Kitagawa, H.; Takenouchi, T.; Azuma, R.; Wesnes, K.A.; Kramer, W.G.; Clody, D.E.; Burnett, A.L. Safety, pharmacokinetics, and effects on cognitive function of multiple doses of GTS-21 in healthy, male volunteers. Neuropsychopharmacology, 2003, 28, 542-551.

[102] Olincy, A.; Harris, J.G.; Johnson, L.L.; Pender, V.; Kongs, S.; Allensworth, D.; Ellis, J.; Zerbe, G.O.; Leonard, S.; Stevens, K.E.; Stevens, J.O.; Martin, L.; Adler, L.E.; Soti, F.; Kem, W.R.; Freedman, R. Proof-of-concept trial of an $\alpha 7$ nicotinic agonist in schizophrenia. Arch. Gen. Psychiatry, 2006, 63, 630-638.

[103] Freedman, R.; Olincy, A.; Buchanan, R.W.; Harris, J.G.; Gold, J.M.; Johnson, L.; Allensworth, D.; Guzman-Bonilla, A.; Clement, B.; Ball, M.P.; Kutnick, J.; Pender, V.; Martin, L.F.; Stevens, K.E.; Wagner, B.D.; Zerbe, G.O.; Soti, F.; Kem, W.R. Initial phase 2 trial of a nicotinic agonist in schizophrenia. Am. J. Psychiatry, 2008, $165,1040-1047$.

[104] Hashimoto, K. Nausea associated with a nicotinic agonist therapy in schizophrenia. Clin. Psychopharmacol. Neurosci., 2009; 7, 2627.

[105] Mullen, G.; Napier, J.; Balestra, M.; DeCory, T.; Hale, G.; Macor, J.; Mack, R.; Loch, J. $3^{\text {rd }}$; Wu, E.; Kover, A.; Verhoest, P.; Sampognaro, A.; Phillips, E.; Zhu, Y.; Murray, R.; Griffith, R.; Blosser, J.; Gurley, D.; Machulskis, A.; Zongrone, J.; Rosen, A.; Gordon, J. (-)-Spiro[1-azabicyclo[2.2.2]octane-3,5'-oxazolidin-2'one], a conformationally restricted analogue of acetylcholine, is a highly selective full agonist at the $\alpha 7$ nicotinic acetylcholine receptor. J. Med. Chem., 2000, 43, 4045-4050.

[106] Grottick, A.J.; Trube, G.; Corrigall, W.A.; Huwyler, J.; Malherbe, P.; Wyler, R.; Higgins, G.A. Evidence that nicotinic $\alpha 7$ receptors are not involved in the hyperlocomotor and rewarding effects of nicotine. J. Pharmacol. Exp. Ther., 2000, 294, 1112-1119.

[107] Grottick, A.J.; Wyler, R.; Higgins, G.A. The $\alpha 4 \beta 2$ agonist SIB $1765 \mathrm{~F}$, but not the $\alpha 7$ agonist AR-R 17779, cross-sensitises to the psychostimulant effects of nicotine. Psychopharmacology, (Berl.), 2000, 150, 233-236.

[108] Levin, E.D.; Bettegowda, C.; Blosser, J.; Gordon, J. AR-R17779, and $\alpha 7$ nicotinic agonist, improves learning and memory in rats. Behav. Pharmacol., 1999, 10, 675-680.

[109] Sydserff, S.; Sutton, E.J.; Song, D.; Quirk, M.C.; Maciag, C.; Li, C.; Jonak, G.; Gurley, D.; Gordon, J.C.; Christian, E.P.; Doherty, J.J.; Hudzik, T.; Johnson, E.; Mrzljak, L.; Piser, T.; Smagin, G.N.; Wang, Y.; Widzowski, D.; Smith, J.S. Selective $\alpha 7$ nicotinic receptor activation by AZD0328 enhances cortical dopamine release and improves learning and attentional processes. Biochem. Pharmacol., 2009, 78, 880-888.

[110] Macor, J.E.; Wu, E. Azabicyclic esters of carbamic acids useful in therapy. International Application No.: PCT/SE1997/000294, WO 97/30998, Aug. 28, 1997.

[111] Tatsumi, R.; Seio, K.; Fujio, M.; Katayama, J.; Horikawa, T.; Hashimoto, K.; Tanaka, H. (+)-3-[2-(Benzo[b]thiophen-2-yl)-2oxoethyl]-1- azabicyclo[2.2.2] octane as potent agonists for the $\alpha 7$ nicotinic acetylcholine receptor. Bioorg. Med. Chem., 2004, 14, 3781-3784.

[112] Tatsumi, R.; Fujio, M.; Satoh, H.; Katayama, J.; Takanashi, S.; Hashimoto, K.; Tanaka, H. Discovery of the $\alpha 7$ nicotinic acetylcholine receptor agonists. (R)-3'-(5-Chlorothiophen-2-

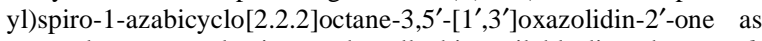
a novel, potent, selective, and orally bioavailable ligand. J. Med. Chem., 2005, 48, 2678-2686.

[113] Tatsumi, R.; Fujio, M.; Takanashi, S.; Numata, A.; Katayama, J.; Satoh, H.; Shiigi, Y.; Maeda, J.; Kuriyama, M.; Horikawa, T.; Murozono, T.; Hashimoto, K.; Tanaka, H. $(R)-3^{\prime}-(3-$ methylbenzo[b]thiophen-5-yl)spiro[1- azabicyclo[2,2,2]octane$3,5^{\prime}$-oxazolidin]-2'-one, a novel and potent $\alpha 7$ nicotinic acetylcholine receptor partial agonist displays cognitive enhancing properties. J. Med. Chem., 2006, 49, 4374-4383.

[114] Marrero, M.B.; Papke, R.L.; Bhatti, B.S.; Shaw, S.; Bencherif, M. The neuroprotective effect of 2-(3-pyridyl)-1azabicyclo[3.2.2]nonane (TC-1698), a novel $\alpha 7$ ligand, is prevented through angiotensin II activation of a tyrosine phosphatase. J. Pharmacol. Exp. Ther., 2003, 309, 16-27.

[115] Marzurov, A.; Klucil, J.; Miao, L.; Philips, T.Y.; Seamans, A.; Schmitt, J.D.; Hauser T.A.; Johnson Jr., R.T.; Miller, C. 2(Arylmethyl)-3-substituted quinuclidines as selective $\alpha 7$ nicotinic receptor ligands. Bioorg. Med. Chem. Lett., 2005, 15, 2073-2077.

[116] Hauser, T.A.; Kucinski, A.; Jordan, K.G.; Gatto, G.J.; Wetsinger, S.R.; Hesse, R.A.; Stachowiak, E.K.; Stachowiak, M.K.; Papke, R.L.; Lippiello, P.M.; Bencherif, M. TC-5619: an $\alpha 7$ neuronal nicotinic receptor-selective agonist that demonstrates efficacy in animal models of the positive and negative symptoms and cognitive dysfunction of schizophrenia. Biochem. Pharmacol., 2009, 78, 803-812.

[117] Bodnar, A.L.; Cortes-Burgos, L.A.; Cook, K.K.; Dinh, D.M.; Groppi, V.E.; Hajos, M.; Higdon, N.R.; Hoffmann, W.E.; Hurst, R.S.; Myers, J.K.; Rogers, B.N.; Wall, T.M.; Wolfe, M.L.; Wong, E. Discovery and structure-activity relationship of quinuclidine benzamides as agonists of $\alpha 7$ nicotinic acetylcholine receptors. $J$. Med. Chem., 2005, 48, 905-908.

[118] Hajós, M.; Hurst, R.S.; Hoffmann, W.E.; Krause, M.; Wall, T.M.; Higdon, N.R.; Groppi, V.E. The selective $\alpha 7$ nicotinic acetylcholine receptor agonist PNU-282987 [N-[(3R)-1Azabicyclo[2.2.2]oct-3-yl]-4-chlorobenzamide hydrochloride] enhances GABAergic synaptic activity in brain slices and restores auditory gating deficits in anesthetized rats. J. Pharmacol. Exp. Ther., 2005, 312, 1213-1222.

[119] Wishka, D.G.; Walker, D.P.; Yates, K.M.; Reitz, S.C.; Jia, S.; Myers, J.K.; Olson, K.L.; Jacobsen, E.J.; Wolfe, M.L.; Groppi, V.E.; Hanchar, A.J.; Thornburgh, B.A.; Cortes-Burgons, L.A.; Wong, E.H.F.; Staton, B.A.; Raub, T.J.; Higdon, N.R.; Wall, T.M.; Hurst, R.S.; Walters, R.R.; Hoffmann, W.E.; Hajos, M.; Franklin, S.; Carey, G.; Gold, L.H.; Cook, K.K.; Sands, S.B.; Zhao, S.X.; Soglia, J.R.; Kalgutkar, A.S.; Arneric, A.P.; Rogers, B.N. Discovery of $N$-[(3R)-1-azabicyclo[2.2.2]oct-3-yl]furo[2,3c]pyridine-5-carboxamide, an agonist of the $\alpha 7$ nicotinic acetylcholine receptor, for the potential treatment of cognitive deficits in schizophrenia: synthesis and structure-activity relationship. J. Med. Chem., 2006, 49, 4425-4436.

[120] Walker, D.P.; Wishka, D.G.; Piotrowski, D.W.; Jia, S.; Reitz, S.C.; Yates, K.M.; Myers, J.K.; Vetman, T.N.; Margolis, B.J.; Jacobsen, 
E.J.; Acker, B.A.; Groppi, V.E.; Wolfe, M.L.; Thornburgh, B.A.; Tinholt, P.M.; Cortes-Burgos, L.A.; Walters, R.R.; Hester, M.R.; Seest, E.P.; Dolak, L.A.; Han, F.; Olson, B.A.; Fitzgerald, L.; Staton, B.A.; Raub, T.J.; Hajos, M.; Hoffmann, W.E.; Li, K.S.; Higdon, N.R.; Wall, T.M.; Hurst, R.S.; Wong, E.H.F.; Rogers, B.N. Design, synthesis, structure-activity relationship, and in vivo activity of azabicyclic aryl amides as $\alpha 7$ nicotinic acetylcholine receptor agonists. Bioorg. Med. Chem., 2006, 14, 8219-8248.

[121] Acker, B.A.; Jacobsen, E.J.; Rogers, B.N.; Wishka, D.G.; Reitz, S.C.; Piotrowski, D.W.; Myers, J.K.; Wolfe, M.L.; Groppi, V.E.; Thornburgh, B.A.; Tinholt, P.M.; Walters, R.R.; Olson, B.A.; Fitzgerald, L.; Staton, B.A.; Raub, T.J.; Krause, M.; Li, K.S.; Hoffmann, W.E.; Hajos, M.; Hurst, R.S.; Walker, D.P. Discovery of $N$-[(3R,5R)-1-azabicyclo[3.2.1]oct-3-yl]furo-[2,3-c]pyridine- 5carboxamide as an agonist of the $\alpha 7$ nicotinic acetylcholine receptor: in vitro and in vivo activity. Bioorg. Med. Chem. Lett., 2008, 18, 3611-3615.

[122] Biton, B.; Bergis, O.E.; Galli, F.; Nedelec, A.; Lochead, A.W.; Jegham, S.; Godet, D.; Lanneau, C.; Santamaria, R.; Chesney, F.; Léonardon, J.; Granger, P.; Debono, M.W.; Bohme, G.A.; Sgard, F.; Besnard, F.; Graham, D.; Coste, A.; Oblin, A.; Curet, O.; Vigé, X.; Voltz, C.; Rouquier, L.; Souihac, J.; Santucci, V.; Gueudet, C.; Françon, D.; Steinberg, R.; Griebel, G.; Oury-Donat, F.; George, P.; Avenet, P.; Scatton, B. SSR180711, a novel selective $\alpha 7$ nicotinic receptor partial agonist: (I) binding and functional profile. Neuropsychopharmacology, 2007, 32, 1-16.

[123] Pichat, P.; Bergis, O.E.; Terranova, J.-P.; Urani, A.; Duarte, C.; Santucci, V.; Gueudet, C.; Voltz, C.; Steinberg, R.; Stemmelin, J.; Oury-Donat, F.; Avenet, P.; Griebel, G.; Scatton, B. SSR180711, a novel selective $\alpha 7$ nicotinic receptor partial agonist: (II) efficacy in experimental models predictive of activity against cognitive symptoms of schizophrenia. Neuropsychopharmacology, 2007, 32, 17-34.

[124] Hashimoto, K.; Ishima, T.; Fujita, Y.; Matsuo, M.; Kobashi, T.; Takahagi, M.; Tsukada, H.; Iyo, M. Phencyclidine-induced cognitive deficits in mice are improved by subsequent subchronic administration of the novel selective $\alpha 7$ nicotinic receptor agonist SSR180711. Biol. Psychiatry, 2008, 63, 92-97.

[125] Thomsen, M.S.; Christensen, D.Z.; Hansen, H.H.; Redrobe, J.P.; Mikkelsen, J.D. $\alpha 7$ Nicotinic acetylcholine receptor activation prevents behavioral and molecular changes induced by repeated phencyclidine treatment. Neuropharmacology, 2009, 56, 10011009.

[126] Barak, S.; Arad, M.; De Levie, A.; Black, M.D.; Griebel, G.; Weiner, I. Pro-cognitive and antipsychotic efficacy of the $\alpha 7$ nicotinic partial agonist SSR180711 in pharmacological and neurodevelopmental latent inhibition models of schizophrenia. Neuropsychopharmacology, 2009, 34, 1753-1763.

[127] Moser, P.C.; Hitchcock, J.M.; Lister, S.; Moran, P.M. The pharmacology of latent inhibition as an animal model of schizophrenia. Brain Res. Brain Res. Rev., 2000, 33, 275-307.

[128] Weiner, I. The "two-headed" latent inhibition model of schizophrenia: modeling positive and negative symptoms and their treatment. Psychopharmacology (Berl.), 2003, 169, 257-297.

[129] Hansen, H.H.; Timmermann, D.B.; Peters, D.; Walters, C.; Damaj, M.I.; Mikkelsen, J.D. $\alpha 7$ nicotinic acetylcholine receptor agonists selectively activate limbic regions of the rat forebrain: an effect similar to antipsychotics. J. Neurosci. Res., 2007, 85, 1810-1818.

[130] Kristensen, S.E.; Thomsen, M.S.; Hansen, H.H.; Timmermann, D.B.; Hay-Schmidt, A.; Mikkelsen, J.D. The $\alpha 7$ nicotinic receptor agonist SSR180711 increases activity regulated cytoskeleton protein (Arc) gene expression in the prefrontal cortex of rat. Neurosci. Lett., 2007, 418, 154-158.

[131] Søderman, A.; Thomsen, M.S.; Hansen, H.H.; Nielsen, E.Ø.; Jensen, M.S.; West, M.J.; Mikkelsen, J.D. The nicotinic $\alpha 7$ acetylcholine receptor agonist SSR180711 is unable to activate limbic neurons in mice overexpressing human amyloid- $\beta_{1-42}$. Brain Res., 2008, 1227, 240-247.

[132] Haydar, S.N.; Ghiron, C.; Bettinetti, L.; Bothmann, H.; Comery, T.A.; Dunlop, J.; LaRosa, S.; Micco, I.; Pollastrini, M.; Quinn, J.; Roncarati, R.; Scali, C.; Valacchi, M.; Varrone, M.; Zanaletti, R. SAR and biological evaluation of SEN12333/WAY-317538: novel $\alpha 7$ nicotinic acetylcholine receptor agonist. Bioorg. Med. Chem., 2009, 17, 5247-5258.

[133] Roncarati, R.; Scali, C.; Comery, T.A.; Grauer, S.M.; Aschmi, A.; Bothmann, H.; Jow, B.; Kowai, D.; Gianfriddo, M.; Kelley, C.;
Zanelli, U.; Ghiron, C.; Haydar, S.; Duniop, J.; Terstappen, G.C. Procognitive and neuroprotective activity of a novel $\alpha 7$ nicotinic acetyl choline receptor agonist for treatment of neurodegenerative and cognitive disorders. J. Pharmacol. Exp. Ther., 2009, 329, 459468.

[134] Boess, F.G.; Vry, J.D.; Erb, C.; Flessner, T.; Hendrix, M.; Luithle, J.; Methfessel, C.; Riedl, B.; Schnizler, K.; van der Staay, F.-J.; van Kampen, M.; Wiese, W.B.; Koenig, G. The novel $\alpha 7$ nicotinic acetylcholine receptor agonist $N-[(3 R)-1$-azabicyclo[2.2.2]oct-3yl]-7-[2-(methoxy)phenyl]-1-benzofuran-2-carboxamide improves working and recognition memory in rodents. J. Pharmacol. Exp. Ther., 2007, 321, 716-725.

[135] Briggs, C.A.; Schrimpf, M.R.; Anderson, D.J.; Gubbins, E.J.; Grønlien, J.H.; Håkerud, M.; Ween, H.; Thorin-Hagene, K.; Malysz, J.; Li, J.; Bunnelle, W.H.; Gopalakrishnan, M.; Meyer, M.D. $\alpha 7$ nicotinic acetylcholine receptor agonist properties of tilorone and related tricyclic analogues. Br. J. Pharmacol., 2008, $153,1054-1061$.

[136] Anderson, D.J.; Bunnelle, W.; Suber, B.; Du, J.; Surowy, C.; Tribollet, E.; Marguerat, A.; Bertrand, D.; Gopalakrishnan, M $\left[{ }^{3} \mathrm{H}\right] \mathrm{A}-585539$ [(1S,4S)-2,2-dimethyl-5-(6-phenylpyridazin-3-yl)-5aza-2-azoniabicyclo[2.2.1]heptane], a novel high-affinity $\alpha 7$ neuronal nicotinic receptor agonist: radioligand binding characterization to rat and human brain. J. Pharmacol. Exp. Ther., 2008, 324, 179-187.

[137] Bitner, R.S.; Bunnelle, W.H.; Anderson, D.J.; Briggs, C.A.; Buccafusco, J.; Curzon, P.; Decker, M.W.; Frost, J.M.; Gronlien, J.H.; Gubbins, E.; Li, J.; Malysz, J.; Markosyan, S.; Marsh, K.; Meyer, M.D.; Nikkel, A.L.; Radek, R.J.; Robb, H.M.; Timmermann, D.; Sullivan, J.P.; Gopalakrishnan, M. Broadspectrum efficacy across cognitive domains by $\alpha 7$ nicotinic acetylcholine receptor agonism correlates with activation of ERK1/2 and CREB phosphorylation pathways. J. Neurosci., 2007, 27, 10578-10587.

[138] Tietje, K.R.; Anderson, D.J.; Bitner, R.S.; Blomme, E.A.; Brackemeyer, P.J.; Briggs, C.A.; Browman, K.E.; Bury, D.; Curzon, P.; Drescher, K.U.; Frost, J.M.; Fryer, R.M.; Fox, G.B.; Gronlien, J.H.; Håkerud, M.; Gubbins, E.J.; Halm, S.; Harris, R.; Helfrich, R.J.; Kohlhaas, K.L.; Law, D.; Malysz, J.; Marsh, K.C.; Martin, R.L.; Meyer, M.D.; Molesky, A.L.; Nikkel, A.L.; Otte, S.; Pan, L.; Puttfarcken, P.S.; Radek, R.J.; Robb, H.M.; Spies, E.; Thorin-Hagene, K.; Waring, J.F.; Ween, H.; Xu, H.; Gopalakrishnan, M.; Bunnelle, W.H. Preclinical characterization of A-582941: a novel $\alpha 7$ neuronal nicotinic receptor agonist with broad spectrum cognition-enhancing properties. CNS Neurosci. Ther., 2008, 14, 65-82.

[139] Bitner, R.S.; Nikkel, A.L.; Markosyan, S.; Otte, S.; Puttfarcken, P.; Gopalakrishnan, M. Selective $\alpha 7$ nicotinic acetylcholine receptor activation regulates glycogen synthase kinase $3 \beta$ and decreases tau phosphorylation in vivo. Brain Res., 2009, 1265, 65-74.

[140] Bunnelle, W.H.; Tietje, K.R.; Frost, J.M.; Peters, D.; Ji, J.; Li, T.; Scanio, M.J.C.; Shi, L.; Anderson, D.J.; Dyhring, T.; Grønlien, J.H.; Ween, H.; Thorin-Hagene, K.; Meyer, M.D. Octahydropyrrolo[3,4-c]pyrrole: a diamine scaffold for construction of either $\alpha 4 \beta 2$ or $\alpha 7$-selective nicotinic acetylcholine receptor (nAChR) ligands. Substitutions that switch subtype selectivity. J. Med. Chem., 2009, 52, 4126-4141.

[141] Feuerbach, D.; Nozulak, J.; Lingenhoehl, K.; McAllister, K.; Hoyer, D. JN403, in vitro characterization of a novel nicotinic acetylcholine receptor $\alpha 7$ selective agonist. Neurosci. Lett., 2007, 416, 61-65.

[142] Feuerbach, D.; Lingenhoehl, K.; Olpe, H.-R.; Vassout, A.; Gentsch, C.; Chaperon, F.; Nozulak, J.; Enz, A.; Bilbe, G.; McAllister, K.; Hoyer, D. The selective nicotinic acetylcholine receptor $\alpha 7$ agonist JN403 is active in animal models of cognition, sensory gating, epilepsy and pain. Neuropharmacology, 2008, 56, 254-263.

[143] Enz, A.; Feuerbach, D.; Frederiksen, M.U.; Gentsch, C.; Hurth, K.; Müller, W.; Nozulak, J.; Roy, B.L. Gamma-lactams - A novel scaffold for highly potent and selective $\alpha 7$ nicotinic acetylcholine receptor agonists. Bioorg. Med. Chem. Lett., 2009, 19, 1287-1291.

[144] Baker, S.R.; Boot, J.; Brunavs, M.; Dobson, D.; Green, R.; Hayhurst, L.; Keenan, M.; Wallace, L. High affinity ligands for the $\alpha 7$ nicotinic receptor that show no cross-reactivity with $5-\mathrm{HT}_{3}$ receptor. Bioorg. Med. Chem. Lett., 2005, 15, 4727-4730.

[145] Rezvani, A.H.; Kholdebarin, E.; Brucato, F.H.; Callahan, P.M.; Lowe, D.A.; Levin, E.D. Effect of R3487/MEM3454, a novel 
nicotinic $\alpha 7$ receptor partial agonist and $5-\mathrm{HT}_{3}$ antagonist on sustained attention in rats. Prog. Neuropsychopharmacol. Biol. Psychiatry, 2009, 33, 269-275.

[146] Sabbagh, M.N. Drug development for Alzheimer's disease: where are we now and where are weheaded? Am. J. Geriatr. Pharmacother., 2009, 7, 167-185.

[147] Lopez-Hernandez, G.; Placzek, A.N.; Thinschmidt, J.S.; Lestage, P.; Trocme-Thibierge, C.; Morain, P.; Papke, R.L. Partial agonist and neuromodulatory activity of S 24795 for $\alpha 7 \mathrm{nAChR}$ responses of hippocampal interneurons. Neuropharmacology, 2007, 53, 134144.

[148] Lagostena, L.; Trocme-Thibierge, C.; Morain, P.; Cherubini, E. The partial $\alpha 7$ nicotinic acetylcholine receptor agonist S 24795 enhances long-term potentiation at CA3-CA1 synapses in the adult mouse hippocampus. Neuropharmacology, 2008, 54, 676-685.

[149] Beracochea, D.; Boucard, A.; Trocme-Thibierge, C.; Morain, P. Improvement of contextual memory by S 24795 in aged mice: comparison with memantine. Psychopharmacology (Berl), 2008, 196, 555-564.

[150] Marighetto, A.; Valerio, S.; Desmedt, A.; Philippin, J.N.; TrocméThibierge, C.; Morain, P. Comparative effects of the $\alpha 7$ nicotinic partial agonist, S 24795, and the cholinesterase inhibitor, donepezil, against age-related deficits in declarative and working memory in mice. Psychopharmacology (Berl), 2008, 197, 499-508.

[151] Maricq, A.V.; Peterson, A.S.; Brake, A.J.; Myers, R.M.; Julius, D. Primary structure and functional expression of the $5 \mathrm{HT}_{3}$ receptor, a serotonin-gated ion channel. Science, 1991, 254, 432-437.

[152] Macor, J.E.; Gurley, D.; Lanthorn, T.; Loch, J.; Mack, R.A.; Mullen, G.; Tran, O.; Wright, N.; Gordon, J.C. The 5-HT antagonist tropisetron (ICS 205-930) is a potent and selective $\alpha 7$ nicotinic receptor partial agonist. Bioorg. Med. Chem. Lett., 2001, 11,319-321.

[153] Papke, R.L.; Porter Papke, J.K.; Rose, G.M. Activity of $\alpha 7-$ selective agonists at nicotinic and serotonin 5HT3 receptors expressed in Xenopus oocytes. Bioorg. Med. Chem. Lett., 2004, 14, 1849-1853.

[154] Hashimoto, K.; Iyo, M.; Freedman, R.; Stevens, K.E. Tropisetron improves deficient inhibitory auditory processing in DBA/2 mice: role of $\alpha 7$ nicotinic acetylcholine receptors. Psychopharmacology (Berl), 2005, 183, 13-19.

[155] Hashimoto, K.; Fujita, Y.; Ishima, T.; Hagiwara, H.; Iyo, M. Phencyclidine-induced cognitive deficits in mice are improved by subsequent subchronic administration of tropisetron: Role of $\alpha 7$ nicotinic receptors. Eur. J. Pharmacol., 2006, 553, 191-195.

[156] Koike, K.; Hashimoto, K.; Takai, N.; Shimizu, E.; Komatsu, N.; Watanabe, H.; Nakazato, M.; Okamura, N.; Stevens, K.E.; Freedman, R.; Iyo, M. Tropisetron improves deficits in auditory P50 suppression in schizophrenia. Schizophr Res., 2005, 76, 67-72.

[157] Toyohara, J.; Wu, J.; Hashimoto, K. Recent development of radioligands for imaging $\alpha 7$ nicotinic acetylcholine receptors in the brain. Curr. Top. Med. Chem., 2010, (in press).

[158] Hashimoto, K.; Nishiyama, S.; Ohba, H.; Matsuo, M.; Kobashi, T.; Takahagi, M.; Iyo, M.; Kitashoji, T.; Tsukada, H. [ $\left.{ }^{11} \mathrm{C}\right] \mathrm{CHIBA}-$ 1001 as a novel PET ligand for $\alpha 7$ nicotinic receptors in the brain: A PET study in conscious monkeys. PLoS One, 2008, 3, e3231.

[159] Toyohara, J.; Sakata, M.; Wu, J.; Ishikawa, M.; Oda, K.; Ishii, K.; Iyo, M.; Hashimoto, K.; Ishiwata, K. Preclinical and the first clinical studies on $\left[{ }^{11} \mathrm{C}\right] \mathrm{CHIBA}-1001$ for mapping $\alpha 7$ nicotinic receptors by positron emission tomography. Ann. Nucl. Med., 2009 $23,301-309$.

(C) Toyohara and Hashimoto; Licensee Bentham Open.

This is an open access article licensed under the terms of the Creative Commons Attribution Non-Commercial License (http: //creativecommons.org/licenses/by$\mathrm{nc} / 3.0 /$ ) which permits unrestricted, non-commercial use, distribution and reproduction in any medium, provided the work is properly cited. 